\title{
Employing Trafficking Laws to Capture Elusive Leaders of Destructive Cults
}

I. Cults-An Overview..................................................209

A. The Case of Elissa Wall Against FLDS …..............210

B. Four Processes of Indoctrination............................213

1. Thought Control ...............................................214

2. Behavior Control, Emotional Control, and Information Control.........................................218

C. Five Types of Cults .............................................219

1. Religious Cults ...............................................221

\begin{abstract}
* I take no position about whether any of the organizations described in this writing are in facts "cults," but instead I rely upon reported accounts of their activities to argue that trafficking laws could be employed in ways not originally contemplated when the laws were enacted. For explanation of characteristics of cults, Michael D. Langone provides a widely cited list titled, "Characteristics of Cultic Groups." See infra Appendix. I express sincere gratitude to Mike Kropveld, Executive Director of Info-Secte Cult, Canada, for presenting an excerpt of this paper at an academic conference for the Center for the Study of Cultic Groups \& Religious Culture, Beijing Union University, on August 16, 2015, in Beijing, China. On American soil, I presented this paper at a community forum held at the Garden City Community Church, New York, on October 26, 2015.

Additionally, I thank St. John's University School of Law for providing me with a summer research stipend to write this Article. My gratitude is further extended to the following professors, practitioners, and experts in their respective fields, all of whom read my drafts and provided helpful comments: Marc DeGirolami, Professor of Law, Assoc. Dean for Faculty Scholarship, and Assoc. Director of Center for Law and Religion at St. John's Law; my husband, Paul Skip Laisure, Esq., supervisor at Appellate Advocates, a nonprofit criminal defense law firm in NYC; Michael D. Langone, PhD, Executive Director of ICSA and Editor-in-Chief, ICSA Today; Theresa Tebbett, Esq., Deputy Bureau Chief, District Court Bureau, Nassau County District Attorney's Office, NY; and Aylin Ictemel, Assistant Attorney General, Criminal Division, Office of the N.Y.S. Attorney General. This Article is dedicated to the 276 children who perished in Jonestown and to the tragic deaths of others born into cults and have met their peril.
\end{abstract}


2. Political Cults

3. Terrorist Groups as Cults ...............................222

4. Psychotherapy Cults .........................................224

5. Commercial Cults.............................................225

D. Cults and the Law................................................225

1. U.S. Law Strongly Protects Religion ...............225

2. U.S. Evidence Rules Generally Impair Prosecutors' Ability to Introduce Evidence of Brainwashing and Coercion ............................227

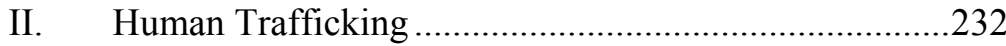

A. Laws Prohibiting Human Trafficking ...................233

1. International Laws ........................................233

2. Protections for Trafficking Victims Under International Law ............................................234

3. Legal Effect of the International Treaties.........235

4. United States Laws Prohibiting Human Trafficking....................................................236

5. How U.S. Federal Law Is Changing.................237

B. Cults Compared with Human Trafficking Rings ...239

1. Physical Force, Threats, Malnourishment ........239

2. Psychological Coercion and Surveillance ........240

3. Labor and Profit Motives ................................241

4. Fraudulent Recruitment ...................................242

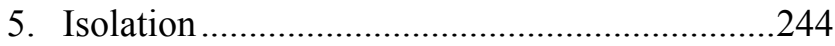

6. Shaming Tactics .............................................24

C. Human Trafficking as Distinguishable from Other Crimes ..................................................................245

III. Using Human Trafficking Strategies to Combat Destructive Cults .......................................................2246

A. Applying Criminal Trafficking Statutes to Prosecute Cult Leaders ...........................................................246

B. Suggestions for Expanding Resources to Identify and Support Cult Victims............................................248

1. Violence Against Women ................................248

2. Training Programs .........................................249

3. Providing Victims' Rights to Former Cult Members ......................................................250

4. Sharing Resources with Programs that Help Identify Child Victims.......................................251

C. A Case in Point....................................................251

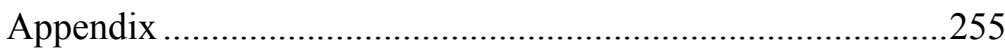


In the 1970 s and ' 80 s in the United States, American newspapers raised public awareness about cults. ${ }^{1}$ Capturing headlines were articles about women, and later men, who followed Charles Manson ${ }^{2}$ to the extreme length of committing "Helter Skelter," a cold-blooded killing spree. ${ }^{3}$ Cult activity continued to exist, out of sight and unobserved, until culminating in tragedy when it would, again, become the topic of a news story. Even when cults did not achieve "front-page" status in the news, they continued to recruit adults and raise children born into the group.

Because cults are undocumented and are not calculated by the U.S. census, it is difficult to estimate how many are in the United States today. ${ }^{4}$ Estimates range from 2,500 to 8,000 cults with membership ranging from a few individuals to tens of thousands in any given cult. ${ }^{5}$ According to the International Cultic Studies Association ("ICSA"), an organization that monitors cults and provides education and counseling, approximately 2,500,000 Americans have joined cultic groups since the 1970s. ${ }^{6}$

1 The term "cult" is more commonly used in the United States; whereas, "sect" is used more prevalently in Europe. See Ana Ballesteros Peiro et al., The Red Mosque: A Case Study of How Religion Can Evolve into a Terrorist Cult, 8 CULTIC STUD. REV. 266, 267 (2009); Janja Lalich, The Violent Outcomes of Ideological Extremism: What Have We Learned Since Jonestown?, 8 CULTIC STUD. REV. 281, 294 n.97 (2009) [hereinafter Violent Outcomes] (explaining the origin and meaning of the word "cult")

2 In denying defense counsel's motion to change the venue, the court summarized the publicity this way:

the undeniably extensive news media coverage received by this case gives rise to appellants' claim that publicity denied them a fair and impartial trial. When the crimes were discovered in August of 1969 they were greatly publicized. The media's revelations focused primarily on the savageness of the killings, the absence of clues revealing the identity of the perpetrators, and certain details about the private lives and relationships of the victims. Particular emphasis was given to the Tate murder because one of the victims was a movie actress.

Concluding that the publicity was so extensive throughout the state, that a change of venue would be of no value, the court denied the motion. People v. Manson, 61 Cal. App. 3d 102 (Cal. Ct. App. 1976).

3 Id. at 129.

4 See generally Michael D. Langone, Ph.D., Prevalence, InT'L CUlTiC STUD. Ass'N, http://www.icsahome.com/articles/prevalence (last visited May 10, 2016)(“an unknown, but not insignificant, number of people have been born and raised in cultic groups").

5 Susan Landa, Children and Cults: A Practical Guide, 29 J. FAM. L. 591, 591 n.1 (1991).

6 See Herbert L. Rosedale\& Michael D. Langone, On Using the Term “Cult," INT'L CULTIC STUD. ASS'N, http://www.icsahome.com/articles/onusingtermcult (last visited May 10, 2016); Langone, supra note 4 (reporting 3\% of San Francisco Bay area high school students being members of cults (1985) and $1.5 \%-3 \%$ of high school students in two Boston 
Some cults are benign, others destructive; cults may change over time, sometimes from benign to destructive, sometimes vice versa. ${ }^{7}$ Benign cults appear not to inflict physical or emotional trauma to their members. ${ }^{8}$ In contrast, destructive cults do harm their members and are characterized by exploitative, manipulative, and controlling interpersonal dynamics. ${ }^{9}$

Destructive cults are the focus of this paper. Cults continue to evade our justice system here in the United States and abroad. This paper seeks to offer a fresh legal framework which, I posit, could aid in the capture and prosecution of cult leaders. In Part I, I describe how cults function. In Subpart (A), I describe a young girl's (Elissa Wall) tragic marriage into a lifetime, and expected eternity, with a relative whom she initially resisted. In Subpart (B), I explain the four processes of control employed by cults, which involve the mind, behavior, emotion and information. In Subpart (C), cults are categorized as religious, political, terrorist, psychotherapy, and commercial. The U.S. legal system's inability to provide sufficient remedies to those harmed by cult activity is set forth in Subpart (D). In Part II, international and American efforts to prevent and combat trafficking are presented. In Part III, I posit that law enforcement and the international community

suburbs (1984). ICSA's website describes the organization, founded in 1979, as "a global network of people concerned about psychological manipulation and abuse in cultic or highdemand groups, alternative movements, and other environments." INT'L CULTIC STUD. ASS'N, http://www.icsahome.com/aboutus (last visited May 10, 2016). ICSA provides guidance, counseling, and support to former cultic members and their families. Id. Through extensive programming at workshops and conferences held around the world annually, it provides education in fora where researchers, lawyers, doctors, counselors, academics, former cult members, and families come together to educate themselves and the public about cults and healing.

7 See Landa, supra note 5, at 591. See generally InT'L CULTIC STUD. Ass'N, $\mathrm{http}: / / w w w . i c s a h o m e . c o m /$ elibrary/studyguides/research (last visited May 10, 2016) (Harm to cult members is real and not merely a subjective judgment.); Michael D. Langone, Academic Disputes and Dialogue Collection: Preface. ICSA E-NEWSLETTER, 4(3) (2005); Jodi Aronoff McKibben et al., Are Cultic Environments Psychologically Harmful?, CulTIC STUD. REV., 1(3) (2002); Carmen Almendros et al., Assessment of Psychological Abuse in Manipulative Groups, 2 INT'L J. CULTIC STUD. 61-76 (2011); Seth M. Asser \& Rita Swan, Child Fatalities from Religion-Motivated Neglect, 17 CULTIC STUD. J. 1-14 (2000); Carmen Almendros et al., Former Members' Perceptions of Cult Involvement 6 CULTIC STUD. REV. 1-20 (2007); Stephen A. Kent, House of Judah, the Northeast Kingdom Community, and the Jonestown Problem: Downplaying Child Physical Abuses and Ignoring Serious Evidence 1 INT'L J. CULTiC STUD. 27-48 (2010); Carmen Almendros et al., Reasons for Leaving: Psychological Abuse and Distress Reported by Former Members of Cultic Groups 8 CULTIC STUD. REV. 111-38 (2009).

8 Landa, supra note 5, at 591.

9 See generally id. 
use anti-trafficking laws and resources to capture cult leaders, prosecute them for the harm that they inflict on their adherents, and provide services to former cult members. In this way, the religious or political dogma of cults - often an obstacle to holding them accountable for their criminal behavior-is no longer a barrier to prosecution.

I

\section{CUlts-An OVERVIEW}

To begin, "cult" is a fluid definition. Cults are organized groups, often with a basis in religion. ${ }^{10}$ Cults, by virtue of the power that they exert over their devotees, have the propensity to be harmful, and some are harmful, but others are not. ${ }^{11}$ In sum, cults are at risk of perpetuating harm. ${ }^{12}$

Those that have crossed the line, destructive cults, have common traits. As one researcher explained, these cults share three characteristics: "(1) a charismatic leader who increasingly becomes an object of worship as the general principles that may have originally sustained the group lose their power; (2) a process . . . call[ed] coercive persuasion or thought reform; (3) economic, sexual, and other exploitation of group members by the leader and the ruling coterie." 13 The leader often tells a unique story about the foundation of the organization that elevates this group or religion above all others. ${ }^{14}$ The leader claims to be the chosen one, selected by some supreme being, and frequently preaches that followers will find salvation after death. ${ }^{15}$ The leader is the only member with a true understanding of the religion and, thus, all information must flow through the leader. ${ }^{16}$

\footnotetext{
$10 \mathrm{Id}$. at 593.

11 See Arthur A. Dole \& Steve K. Dubrow-Eichel, Some New Religions are Dangerous 2 CUlTiC STUD. J. 17-30 (1985).

12 See Rosedale \& Langone, supra note 6.

13 See Lita Linzer Schwartz, The Millennium is Here-and So are the Cults, 18 CULTIC Stud. J. 82, 83 (2001) (citing Lifton, R.J., Cult Formation, 8(1) CUlTiC STUD. J. 1, 2 (1991)).

14 See Joseph Szimhart, Razor's Edge Indeed: A Deprogrammer's View of Harmful Cult Activity, 8 CULTIC STUD. REV. 231 (2009).

15 Id. at 241. "The leader and group will supply the new recruit with an interesting foundation myth that supports the leader's claims to authority. The foundation myth generally reflects a profound spiritual experience and private journey the leader has taken." Id.

$16 I d$. at 243.
} 
A more detailed list of common traits shared by cults is provided in the Appendix. ${ }^{17}$

Given this definition, one might wonder what distinguishes traditional religious affiliation from cult affiliation. The late Herbert Rosedale, Esq. ${ }^{18}$ would ask his audience whether they have ever joined a church. Often some members would nod their heads. ${ }^{19}$ And then he would ask them if they knew that they were joining a church when they decided to participate. As a bottom line distinction between what is a religious organization versus a cult, the difference often comes down to the narrow question of whether the adherent knew what kind of group he or she was joining at the outset.

\section{A. The Case of Elissa Wall Against FLDS}

Accounts of cult abuses told by ex-cult members abound. In her autobiography, Elissa Wall described her experience with a cult. ${ }^{20}$ At age fourteen she was forced to marry her first cousin, Allen Steed, who was nineteen. ${ }^{21}$ Both members of the Fundamentalist Church of Jesus Christ of Latter-day Saints ("FLDS"), a polygamous sect, Wall pleaded for a different outcome in the days leading up to the ceremony:

Tears began to pour from my eyes. In all the times I had met with [an elder] since this mess started, I had always tried to maintain my composure, but now, exhausted, hungry, and defeated, I broke down in front of him. Seeing this opening, he took the chance to exploit it. I felt the world closing in on me. I hated [the elder] and Uncle Warren [Warren Jeffs], and even my mother for putting me in this position. I was fourteen years old with no money and nowhere to go. When my brothers and sister had tested the boundaries of rebellion, they had

17 See Michael D. Langone, Characteristics Associated with Cultic Groups, INT'L CULTIC STUD. ASS'N, http://www.icsahome.com/articles/characteristics (last visited May 10, 2016). Since researchers cannot agree on a single definition, here are some descriptive phrases, appearing on ICSA's website, used to define cults: "innovative, fervent groups"; "an ideological organization held together by charismatic relationships and demanding total commitment"; "groups at high risk of becoming abusive because of members' adulation of its leaders"; and "a continuum, in which large gray area separates cult from noncult."

18 People Profiles, INT’L CUlTIC SUTD. ASS'N, http://www.icsahome.com/elibrary /peopleprofiles (last visited May 10, 2016). Herb Rosedale was a practicing attorney and former President of American Family Foundation - name changed to International Cultic Studies Association (ICSA). Mr. Rosedale was of Counsel with Jenkens \& Gilchrist Park Chapin, LLP, and was one of the nation's leading authorities on cults from the late 1970s until his death in 2003.

19 See Richard L. Dowhower, Religion Versus Cults, http://www.icsahome.com/articles /religion-versus-cult-dowhower (last visited May 10, 2016).

20 Elissa Wall, with Lisa Pulitzer, Stolen InNOCEnCE (William Morrow 2008).

21 Id. at $123-24$. 
been shipped off to reform. While that was hard for them, at least it wasn't permanent. Marriage to Allen wasn't just permanent, it was infinite - a punishment that would continue through this life and into the next. ${ }^{22}$

Wall explained that propelling this unhappy union was FLDS spiritual leader, Warren Jeffs. ${ }^{23}$ According to Wall, she was forced to have sexual intercourse with Mr. Steed, as procreation was encouraged by FLDS. ${ }^{24}$ After suffering emotional and physical abuse during the marriage, Wall described how she took a bold step and left Steed. ${ }^{25}$

Outside of FLDS, an attorney met with Wall and explained that "what had happened to [Wall] was criminal." ${ }^{26}$ Wall decided to press criminal charges. ${ }^{27}$ Warren Jeffs was brought to trial by prosecutors in Utah. ${ }^{28}$ In summarizing the case for the jury during the criminal trial, the prosecutor told the jury "[t]he evidence has shown that the only reason that Elissa Wall went into that bedroom and had sexual intercourse with Allen Steed is because that man there [Defendant Warren Jeffs] told her she was supposed to." 29 The prosecutor urged the jury that Jeffs "placed her in a position where she had no choice." 30 The jury found Jeffs guilty of two counts of rape as an accomplice. ${ }^{31}$

Following the verdict, on the courthouse steps, Wall gave a speech. ${ }^{32}$ In words intended for FLDS girls and women, whom she would never be permitted to speak with directly since her ouster from FLDS, Wall advised, "[y]ou do not have to surrender your rights or your spiritual

$22 \mathrm{Id}$. at 144.

23 Id. at 144. See State v. Jeffs, 243 P.3d 1250, 1253, ๆ 9 (Utah 2010) (when Wall sought counseling from the FLDS leaders about the impending marriage, Jeffs told her, "you will go forward with this [marriage.]").

24 WALL, supra note 20, at 144; Jeffs, 243 P.3d at 1253, 111 (at the wedding ceremony, Jeffs pronounced "Now go forth and multiply and replenish the earth with good priesthood children").

25 WALL, supra note 20, at 239-40 (telling her husband she was not returning to him). Wall also filed a civil suit against Jeffs and the FLDS Church seeking monetary damages. Id. at 350 .

$26 I d$. at 349.

$27 \mathrm{Id}$. at 352 . In the criminal case, Jeffs was charged with two counts of rape as an accomplice, a first-degree felony (for the forced marriage of a teenage girl with an older man). Id.

28 Jeffs, 243 P.3d at 1250.

29 WALL, supra note 20, at 415.

$30 \mathrm{Id}$.

31 Jeffs, 243 P.3d at 1250.

32 WALL, supra note 20 , at 420. 
sovereignty. I know how hard it is, but please stand up and fight for your voice and power of choice. I will continue to fight for you." ${ }^{33} \mathrm{Jeffs}$ was sentenced to ten years in prison, ${ }^{34}$ but he appealed. ${ }^{35}$

Reviewing the case on appeal, the Supreme Court of Utah reversed the verdict. ${ }^{36}$ The appellate court agreed with Jeffs that the consent instructions given to the jury were erroneous, warranting a reversal. In analyzing the state's rape statute, the court noted that the defendant must be the "actor" who commits the act of nonconsensual sexual intercourse with the victim. ${ }^{37}$ The Court concluded that Jeffs was not the "actor" as defined in the statute, and that it was erroneous for the trial court to have instructed the jury to equate the statutory term "actor" with the term "defendant." 38 The Supreme Court of Utah's reasoning is indicative of the U.S. justice system's rejection of the theory of undue influence in a cult context. ${ }^{39} \mathrm{Had}$ the court understood that everyone in the church is controlled by the church, then Jeffs may have been found liable because he would have been considered the actor, and the husband his agent. Instead, although the trauma described by what was then a young fourteen-year-old girl is apparent to most outside observers, the American legal system was unable to provide a remedy.

Complicating the situation is the lack of cooperation by would-be victims. For example, Wall described false testimony at the Jeffs' trial, given by fellow FLDS members. ${ }^{40}$ The power of FLDS over its followers and the inability of the authorities to effectively intervene were observed when authorities raided a Texas FLDS compound in the spring of $2008 .^{41}$ The raid was sparked by an anonymous 911 call from an alleged teenager crying for help. ${ }^{42}$ Authorities initiated an extensive interrogation. ${ }^{43}$ The caller was never located. Women and over 400

33 Id. at 422.

34 See generally The Assoc. Press, Texas: 10-Year Sentence for Polygamist Marriages, N.Y. TIMES, Nov. 8, 2011.

35 Id.

36 Jeffs, 243 P.3d at $9 \uparrow$ 53-54, 1260-61.

37 Id. at $33,1257$.

38 Id. Note that having grounded its decision on the erroneous consent instructions, the other issues raised by Jeffs were addressed by the court in dicta. Id. at 939.

39 See id. at $1260-61$.

40 WALL, supra note 20, at 400-13.

41 See generally Kirk Johnson, Texas Polygamy Raid May Pose Risk, N.Y. TIMES, Apr. $12,2008$.

42 Id.

43 Id. 
children were removed from the compound and questioned extensively, but many questions remained unanswered. ${ }^{44}$ The women were unwilling to provide answers to many questions, and, when they did reply, their answers were often false, according to Wall. ${ }^{45}$ After a couple of months, the children were returned to FLDS and no arrests were made. ${ }^{46}$

The child marriage of Wall was not an isolated one, but rather common practice. Warren Jeffs' father, known in FLDS as "Uncle Rulon," has married an estimated seventy-five women and fathered at least sixty-five children. ${ }^{47}$ Uncle Rulon's brides were just fourteen or fifteen years old, even when he aged into his eighties. ${ }^{48}$ And, similar to the personal account of Wall, Uncle Rulon preached "perfect obedience" and "submission." 49

After a failed prosecution in the Walls case, Warren Jeffs was eventually convicted in a Texas court in 2011 for sexual assault committed against two females ages twelve and fifteen. ${ }^{50}$ In contrast, if a trafficker were to falsely advertise on the internet that Wall was a willing bride and then sell her to a would-be husband, the seller would be charged with a criminal act under federal anti-human trafficking statues. Our culture has protected abuses within religious organizations, and our courts have operated with little remedy. ${ }^{51}$ In both instances, there is an under-age marriage and an unwilling bride. ${ }^{52}$ The similarities and distinctions between the two - cults and traffickingare the subject of this paper.

\section{B. Four Processes of Indoctrination}

Why do cults continue to exist and what makes it difficult to prosecute their abusive tactics? When cases go to trial, it is always

44 See id.

45 WALL, supra note 20, at 438.

46 See Janet Heimlich, No Refuge: Five Years After the Infamous Raid on the FLDS Compound in Eldorado, OBSERVER (Aug. 1, 2012, 5:58 PM), http://www.texasobserver .org/no-refuge/.

47 See Jon Krakauer, Under the Banner of Heaven: A Story of Violent Faith 12 (Doubleday 2003).

$48 \mathrm{Id}$.

$49 \mathrm{Id}$.

50 See Whitehurst, Lindsay, Warren Jeffs gets Life in Prison for Sex with Underage Girls, SALT LAKE TRIB., Aug. 11, 2011.

$51 \mathrm{Id}$.

52 See infra. 
possible that witnesses will lie or recant their stories, making prosecution difficult. When cults are on trial, this possibility is exacerbated by "mind control," a pernicious tactic at the root of destructive cults. The legal term for mind control is "undue influence." ${ }^{53}$ Regardless of the term used, the idea is the same: cult leaders gain control over their members by severely restricting their freedom of choice, sometimes through deception, sometimes through intimidation, and sometimes through coercion. ${ }^{54}$

Steven Hassan described his descent into the Unification Church, ${ }^{55}$ an extensive and destructive cult, at least when Hassan was a member. In addition to mind or thought control, Hassan has identified three other processes to explain cult indoctrination: behavior control, emotional control, and information control. ${ }^{56}$ Ultimately, the individual loses his or her freedom of choice.

\section{Thought Control}

Thought control or mind control is described as follows:

[A] system which disrupts an individual's identity. An identity is made up of elements such as beliefs, behavior, thought processes, and emotions that constitute a definite pattern. Under the influence of mind control, a person's authentic original identity given at birth, and as later formed by family, education, friendships, and most importantly that person's own free choices, becomes replaced with another identity, often one that they would not have chosen for themself without tremendous social pressure. ${ }^{57}$

Depending upon the group, to exert undue influence or mind control, cult leaders may also rely on other techniques, including deception in recruitment; fear; physical, sexual, and verbal abuse; and isolation. ${ }^{58}$

53 See Alan W. Scheflin, Supporting Human Rights by Testifying Against Human Wrongs, 6 INT'L J. CULTIC STUD. 69, 70 (2015).

54 "Coercion" is a complex word choice here. The recruited, who is often lured into the cult under false pretenses, is not initially forced to do something he or she does not want to do, and often this new recruit would deny being "coerced." He or she may be manipulated in not choosing what the leader wants, and he may not realize that his choice was constricted as much as somebody who was 'coerced' through threat.

55 Steven Hassan, Combating Cult Mind Control 52-65 (25th Anniv. Ed. Freedom of Mind Press 2015). Formal title of the organization is "The Holy Spirit Association for the Unification of World Christianity." The organization is dubbed the "Moonies" after its leader Sun Myung Moon. As Hassan explains, the Moonies is one of the more visible and destructive cults, both in the United States and worldwide.

56 See id. at $85-87$.

57 Id. at 109 (emphasis in original).

58 See HASSAN, supra note 55. 
Cultic members are often recruited to an organization that they know little about. It is common practice in cultic groups to use deceptive pretenses to lure in followers. ${ }^{59}$ Typically, one would not join these groups if one knew what was in store once inside. Once inside, the individual undergoes a process that results in a loss of freedom of choice. ${ }^{60}$ Unfortunately, it is this aspect of cults that provide obstacles to our judicial system's ability to provide a remedy. Courts have not accepted mind control as an element of traditional crimes. ${ }^{61}$

To inculcate an adherent, cults prey on people's fears. Their followers are fearful that should they leave, they will die by accident or fate (health or otherwise). ${ }^{62}$ Religious cults often preach that deserters are denied salvation. ${ }^{63}$ Elissa Wall described Warren Jeffs threatening her with sacrificial death to rectify the cardinal sin of adultery. ${ }^{64}$ In FLDS, the "sinner" is to be laid out on altar for an ordained elder to commit "blood atonement" by killing her. ${ }^{65}$

Cults use mental, physical and sexual abuse of both adults and children to force compliance. Jonestown is a case in point. ${ }^{66}$ In 1977 , delusional dictator of People's Temple Jim Jones moved approximately 1,000 followers from the west coast of the United States to Guyana, Africa, setting up what was, in effect, a prison camp ("Jonestown"). ${ }^{67}$ There, children were put into dark pits and told that the pits contained snakes. ${ }^{68}$ Members dangled ropes from above to scare them. ${ }^{69}$

In addition to such mental abuse, there are documented accounts of beatings of children in Jonestown. ${ }^{70}$ A former member witnessed her daughter's beating with a board, seventy-five times, for hugging a

59 See id. at 87-89, 103-07. Hassan describes his recruitment into the Moonies.

60 Id.; Scheflin, supra note 53.

61 See Scheflin, supra note 53, at 70-71. To be discussed infra.

62 Janja Lalich, Bounded ChOiCe: TRue Believers and Charismatic Cults 229 (2004) (describing how in Heaven's Gate in the DWP, leaders demanded "total or near-total submission" to the rules governing the group life, with sanctions imposed for those who violated the rules).

63 Id.

64 WALL, supra note 20 , at $317-18$.

65 See id.

66 See HASSAN, supra note 55, at 19, 75.

67 See id.

$68 \mathrm{Id}$.

$69 \mathrm{Id}$. at 105.

$70 \mathrm{Id}$. 
friend whom Jones considered a traitor. ${ }^{71}$ Children were routinely beaten for showing disrespect. ${ }^{72}$ "Belts were used at first, then were replaced by elm switches, which in turn were replaced by the 'board of education,' a long, hard piece of wood, swung by 250-pound [disciplinarian]." ${ }^{, 73}$

Sparked by reports of mistreatment in Jonestown, in 1978, U.S. Congressmen, Senator Leo Ryan, and members of the press visited the compound.$^{74}$ They sensed something was desperately wrong when they received messages from adherents. ${ }^{75}$ Fearing that he was losing control over his followers, Jones set in motion a mass murder and suicide. ${ }^{76}$

The entourage was making its attempt to leave when they were gunned down on the airstrip at Jones' command. ${ }^{77}$ Moments later,

71 Stephen A. Kent, Houseof Judah, the Northeast Kingdom Community, and 'the Jonestown problem': Downplaying Child Physical Abuses and Ignoring Serious Evidence, 1 INT'L J. CULTIC STUD. 27, 30 (2010).

72 KENNETH WOODEN, CHILDREN OF JONESTOWN (1981).

$73 \mathrm{Id}$. at 11 .

74 See WoODEN, supra note 72, at 150-55. Jonestown members complained to Jones of jungle work camp conditions. As Robin D. Willey explains:

Indeed, working and living conditions were harsh, and so were many of the groupenforced social practices, which often involved child abuse, humiliation, harsh punishments for misbehavior, and isolation Eventually, a number of people who were hostile to Jones and Jonestown and who had relatives in the commune formed a group called the Concerned Relatives. The purpose of this group was to raise awareness of the plight of those people who were with Jones. This effort resulted in a governmentsponsored fact-finding mission to Jonestown in November 1978. Congressman Leo J. Ryan . . led this mission, and several members of the media accompanied him. The efforts of the Concerned Relatives played into Jones' paranoia of infringement from the outside.

Robin D. Willey, Religion, Revisionists, and Revolutionary Suicide: A Marxist Framework for the Rise and Fall of Communal Religious Groups, 4 INT'L J. CULTIC STUD. 44-59 (2013).

75 WOODEN, supra note 72.

76 Id. at $159-60$.

After murdering the congressman and some of his entourage, Jones proclaimed that it was time for his people to "die with dignity"; it was time for "revolutionary suicide." On November 18, 1978, more than nine hundred Jonestown residents drank or were forcibly injected with cyanide-laced Flavor-Aid in "protest" of what Jones believed was going to happen to them.

Willey, supra note 74.

77 See Violent Outcomes, supra note 1, at 287; Decoding the Past: Cults Dangerous Devotion (History Channel television broadcast July 18, 2015) [hereinafter Decoding the Past]. Explained in more detail:

[A] group of [Jones's] guards had attacked the US senator Leo Ryan and a group of family members of the disciples, along with journalists who had accompanied Ryan on his visit to the headquarters of the cult to check on the condition of the disciples. 
Jones ordered his followers to drink a lethal substance, killing over 900 people, 276 of whom were children, administered poison by their mothers. $^{78}$

Sexual and physical abuse, prevalent in destructive cults, reinforces undue influence, fear, and paranoia among followers. Often, beatings are publicly displayed for other members to see as a lesson of what would happen should they be disobedient. ${ }^{79}$ For instance, Children of God ("The Family") leader David Berg sexually and physically abused his granddaughter, Merry, at a young age. ${ }^{80}$ Beginning at age seven she was forced to perform sexual acts with her grandfather. ${ }^{81}$ When Merry doubted her "faith" as a young teenager, she was subjected to violent exorcisms involving being spanked with paddles and beaten with rods. ${ }^{82}$ Later, Merry testified in court that "[i]t all felt like torture and once I fainted, throwing up. They said I was throwing up demons. The exorcising terrified me." 8

The Family created camps around the world for problem teenagers. These camps were called "Teen Training Camps" and "Victor Camps." Teenagers endured public beatings, coerced calisthenics, and other atrocities. ${ }^{84}$

These atrocities shape the adherents' minds to submission and control by the destructive cult. ${ }^{85}$ The individual is no longer the former self, but a different self. ${ }^{86}$ However, the theory of mind control is one that our courts have trouble accepting. ${ }^{87}$

Just as they were about to get on the plane to fly home, almost all of them were murdered.

Alvaro Rodriguez-Carballeira et al., A Psychosocial Analysis of the Terrorist Group as a Cult, 1 INT'L J. CUlTIC STUD. 49-60 (2010).

78 See Langone, Responding to Jihadism: A Cultic Studies Perspective, 5 CULTIC STUD. REV. 268, 282 (2006) [hereinafter Jihadism]; Violent Outcomes, supra note 1, at 287; Decoding the Past, supra note 77.

79 See Perry Bulwer, A Response to James D. Chancellor's 'Life in the Family: An Oral History of the Children of God,' 6 CULTIC STUD. REV. 101, 124 (2007).

80 See id. at 124.

$81 \mathrm{Id}$.

$82 \mathrm{Id}$. at 125.

83 Id. (quoting Merry).

84 See Stephen A. Kent \& Deana Hall, Brainwashing \& Re-Indoctrination Programs in the Children of God, 17 CULTIC STUD. J. 56 (2000).

85 HASSAN, supra note 55, at 80-81.

$86 \mathrm{Id}$.

87 See id. at 111. 


\section{Behavior Control, Emotional Control, and Information Control}

Related to mind control is control of one's behavior, emotions, and information. Destructive cults may control behavior by assigning specific tasks for followers to do. Often, followers must ask permission for basic daily occurrences, such as asking for bus fare. ${ }^{88}$

Guilt and fear are tools of the cult leader. ${ }^{89}$ What is outsideauthorities, the devil (evil) - will result in your eternal life in hell. The leaders themselves can harm you if you do not follow their rules. ${ }^{90}$ Punishment is threatened. ${ }^{91}$

A hallmark of destructive cults is information control. Many cults restrict access to news events of the outside world..$^{92}$ The members may have limited information about what is happening within their own organization. ${ }^{93}$ If the cult is located in a remote geographical setting, then isolation from the public and the media can be acute. ${ }^{94}$ However, even where cults exist in urban areas, members may be restricted from interacting with outsiders. ${ }^{95}$ Thus, there is physical as well as psychological isolation. ${ }^{96}$

Isolation is sometimes used in combination with other forms of punishment. ${ }^{97}$ In a lesser-known cult called "The Love of God Community," which was formed in 1970 and disbanded ten years later, cult members were expected to read ten chapters of the Bible every day, along with other Christian books. ${ }^{98}$ Members who failed to comply were physically punished or not spoken to for days. ${ }^{99}$ Eventually, the private beatings intensified to public flogging with a hairbrush and

\footnotetext{
88 See id. at 117.

89 See Alvaro Rodriguez-Carballeira et al., Preliminary Taxonomy of Psychological Abuse Strategies: Within Partner Relationships, at the Workplace, and in Manipulative Groups, 4 INT'L J. CUlTIC STUD. 1, 7 \& tbls.I-III (2013) (providing analysis and classification of abuse strategies).

90 See HASSAN, supra note 55, at 117-18.

91 See id. at 96-98, 125.

$92 \mathrm{Id}$. at 119.

93 See id. at $118-20$.

$94 \mathrm{Id}$. at 119.

95 Id.

96 Telephone Interview with Mike Kropveld, Executive Director of Info-Secte Cult (Aug. 8, 2015).

97 See generally Rodriguez-Carballeira et al., supra note 77 (isolation as a category in group context).

98 See Gille Jenkinson, Cult Pseudo-Creativity vs. Creativity in Recovery, 9 CULTIC STUD. REV. 135, 138 (2010).

99 See id.
} 
bamboo cane. ${ }^{100}$ The cult's leader ordered other members to publicly beat each other, which led to paranoia and fear. ${ }^{101}$ This combination of isolation, paranoia, and fear contributed to leader's ability to exert undue influence on the members.

Women are treated differently than men in most cults, and they are often subjected to worse abuse. ${ }^{102}$ The treatment of women runs the gamut in cults from forced celibacy to prostitution. ${ }^{103}$ Leaders often manipulate women into engaging in sexual relations by describing the acts as a form of honor or duty. ${ }^{104}$ This pattern of sexual abuse applies to children as well. Paul Schaefer, founder of a notorious cult, emigrated from Germany, taking post-World War II German immigrants with him. ${ }^{105} \mathrm{He}$ set up an orphanage outside of Santiago in Chile (establishing "Colonia Dignidad"), which functioned as a cult. He subjected children, particularly the girls, to sexual abuse and torture. ${ }^{106}$ Schaefer was later convicted and sentenced to twenty years in prison for sexually abusing children in the cult. ${ }^{107}$ German-born Harmut Hoppe was convicted as an accomplice to rape and sexual abuse for crimes he committed at Colonia Dignidad. ${ }^{108}$

The ultimate result of undue influence is that the victim loses freedom of choice. The cult member has a new identity. ${ }^{109}$

\section{Five Types of Cults}

A common misconception is that the term "cult" refers only to religious organizations. ${ }^{110}$ Although religious cults are the most notorious, there are also political, terrorist, psychotherapy/educational, and commercial cults. ${ }^{111}$

\footnotetext{
100 See id.

101 See id.

102 See Schwartz, supra note 13, at 89-91.

103 Id. at 60.

104 See id. at 89.

105 Decoding the Past, supra note 77. See also News Summaries, 5 CULTIC STUD. REV. 308 (2006).

106 Decoding the Past, supra note 77. See also News Summaries, 5 Cultic STUD. ReV. 308 (2006).

107 See INT'L CUltic StUd. Ass'N., Colonia Dignidad, www.icsahome.com/groups /coloniadignidad (last visited May 10, 2016).

108 Id.

109 See HASSAN, supra note 55, at 108-10.

110 See id.

111 See HASSAN, supra note 55, at 85-87.
} 
Before exploring the types of cults in depth, however, it is worth considering why a person would join any cult in the first place. Given the abusive nature of cults, who joins them and why? In the United States, there was a noticeable boom of recruitment in the late 1970s and early 1980 s when many college-age adults joined cultic groups. ${ }^{112}$ Perhaps the recruits' vulnerability stemmed from being away from home for the first time and, at that stage of their lives, looking for identity. Since that time, cults have expanded their target populations to the elderly and business executives. ${ }^{113}$ Both of these latter groups are attractive to cults for financial reasons. ${ }^{114}$

Cults target young, generally college-age, persons in systematic fashion. ${ }^{115}$ Typically the cult recruiter initiates conversation, often with a person of the opposite sex, perhaps with flattery or finding a topic of common interest. ${ }^{116}$ Eventually, the potential-inductee is invited to a gathering of other members. ${ }^{117}$ From there, the inductee is typically encouraged to attend long seminars in which he or she is separated from the outside world. ${ }^{118}$

Cult leaders' influence over developing adolescents and children is alarmingly destructive. ${ }^{119}$ Marked differences exist in the personality traits of those entering cults in adolescence or early adulthood and those born into cults. ${ }^{120}$ Those who enter cults during the adolescent stage or later identify with the cult leader and often form a new personality that is superimposed over their own, but they never completely forget their former personality. ${ }^{121}$ In contrast, those born into cults (called "second generation" members) $)^{122}$ display personalities that are more

\footnotetext{
112 See Jihadism, supra note 78, at 272.

113 See Leland E. Shields \& F. Jeri Carter, Healing from Experiences with Unhealthy Spiritual Groups and Cults: Treatment Using Myths and Folk Tales, 18 CULTIC STUD. J. 109, 114 (2001).

114 Id.

115 Richard Delgado, Cults and Conversion: The Case for Informed Consent, 16 GA. L. REV. 533, 546-48 (1982).

116 Id.

117 See id.

118 Id.

$119 \mathrm{Id}$. at 540.

120 See Lorna Goldberg, Raised in Cultic Groups: The Impact on the Development of Certain Aspects of Character, 5 CULTIC STUD. REV. 1, 5 (2006).

121 See id.

122 Researchers use the following terms: "first generation" is used to refer to adults who join cults. "Second generation" is used to refer to children born while their mothers (or parents) are in cults, or young children brought into cults when a parent(s) joins, and these children are raised in cults.
} 
fundamentally shaped by the cult, ${ }^{123}$ reflecting the fact that they have been more affected by it. In either case, the charismatic leader often plays the role of the parent. ${ }^{124}$ Rebellious behavior is squashed by strict discipline, leading to passive personalities in developing children. ${ }^{125}$

\section{Religious Cults}

Religious cults have, at their core, a religious dogma. ${ }^{126}$ Some religious cults, often referred to as "doomsday cults," are focused on the end of the world. ${ }^{127}$ As the 2000 calendar year approached, adherents of these religious cults focused on a possible apocalypse. ${ }^{128}$ For instance, the Branch Davidians in Waco, Texas, led by David Koresh, preached that he was the Lamb of God and that the end of time was soon. ${ }^{129}$ In 1993, eighty members, including twenty-two children, died in a blazing inferno in a confrontation with authorities. ${ }^{130}$ Marshall Applewhite led "Heaven's Gate," another doomsday-type cult. ${ }^{131}$ In 1997, in California, thirty-nine members of Heaven's Gate committed group suicide. ${ }^{132}$

AumShrinrikyo formed a Buddhist-based religion centralized around a theory that thousands of people could be emancipated and gain supernatural powers; he predicted a Third World War or Armageddon in 1999. ${ }^{133}$ After other killings, in March 1995, Aum launched a gas attack on a Tokyo subway system in which 12 people died and 5,000 suffered injuries. ${ }^{134}$

Not all religious cults focus on the imminent end of the world. Others have ongoing ideology and spirituality. ${ }^{135}$ As examples indicate in this Article, at the center of religious cults is the preaching of their

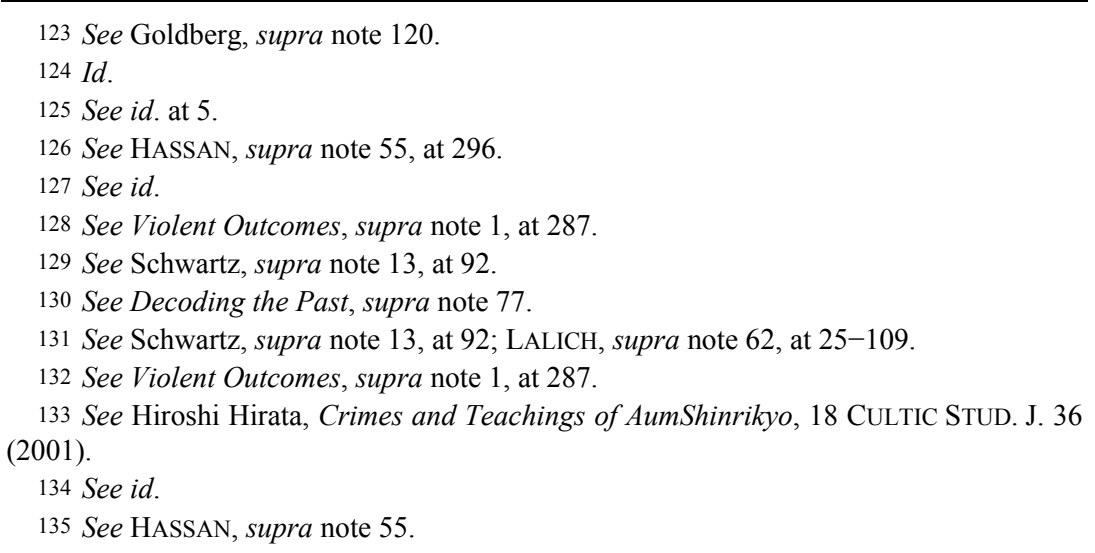


spiritual leader who often claims to have unique knowledge or some connection to the after-world.

\section{Political Cults}

Rather than religion as its tenet, political cults' ideology builds upon a belief that the political system must be changed. One such group is Move, whose headquarters in Philadelphia was bombed by police going after the group's arsenal of weapons. ${ }^{136}$ Move espoused eating raw, "natural" food, holding convictions contrary to the current political system, shunning traditional education of its children, providing rudimentary education to boys only, and the forgoing of materialism. ${ }^{137}$

JanjaLalich joined the Workers Democratic Union ("WDU") and ascended the ranks but later described the group as a small political cult led by a charismatic woman. ${ }^{138}$ The WDU was a feminist, MarxistLeninist party with women leading its upper-ranks. ${ }^{139}$ In October 1985, after twelve years of existence, one hundred members of WDU met in San Francisco and voted to expel their leader, Doreen Baxter, and dissolve the organization. ${ }^{140}$ Baxter was accused of corruption and abuse. $^{141}$

\section{Terrorist Groups as Cults}

Since the September 11, 2001, attacks on America's soil, cult researchers have drawn parallels between terrorist groups with an ideological premise, such as Al Qaeda, and religious cults. ${ }^{142} \mathrm{Al}$ Qaeda had a charismatic, self-appointed leader in Osama bin Laden, and

136 See id. at 86. On May 13, 1985, confrontation by authorities led to the killing of eleven Move members and destruction of sixty homes. See InT'L CUltiC STUD. Ass'N, Move, www.icsahome.com/groups/move (last visited May 10, 2016).

137 See INT'L CULTIC STUD. Ass'N, supra note 136.

138 LALICH, supra note 62, at 113-218.

139 See Janja Lalich, The Cadre Ideal: Origins and Development of a Political Cult, 9 CulTic Stud. J. 1 (1992).

$140 \mathrm{Id}$.

141 Id.

142 In contrast, Masoud Banisadr argues that some terrorist groups should be considered political cults in that they share the cult characteristics of strong charismatic leader, a shared ideology, and isolation. Masoud Banisadr, Terrorist Organizations are Cults, 8 CulTIC STUD. REV. 154, 164 (2009). It is in isolation from wider society that makes a terrorist group dangerous. In order to combat terrorism, Banisadr suggests reducing isolation by forcing them to abide by the moral fabric of the larger society. Id. 
followers were so devoted to their cause ${ }^{143}$ they were willing to commit suicide and mass murder as part of the September 11th attacks. This arguably indicates Al Qaeda's leaders' extreme undue influence over its followers. Thus, Al Qaeda can be characterized as a religious cultic terrorist group. ${ }^{144}$

Another organization that combines terrorism and religious worship is the Lord's Resistance Army ("LRA"), which is centralized in northern Uganda. ${ }^{145}$ Accounts differ on the number of children LRA has abducted, but estimates are over 20,000 children. ${ }^{146}$ The children are forced to terrorize their own communities. ${ }^{147}$ It is estimated the LRA is responsible for the deaths of approximately 100,000 people. ${ }^{148}$ LRA preaches the Acholi religion; its adherents believe that Joseph Kony, their leader, has supernatural powers, making the followers subservient. ${ }^{149}$ Children are preferred recruits over adults because their smaller size allows them to hide effectively in the bush, and because they are fearless when put on the front lines and told to fight without cover. ${ }^{150}$ By exploiting religious beliefs of their followers, the LRA maintains strict allegiance. ${ }^{151}$ Thus, LRA would be characterized as a terrorist cult.

One of the distinctions between a political cult operating as a terrorist organization and a "traditional" cult is that the terrorist group is centered on the destruction of others outside its group, whereas a religious cult is destructive to its own members. ${ }^{152}$ Heaven's Gate, for example, did not exhibit "terrorist" behavior because its destruction was inward towards its own members. ${ }^{153}$ Nevertheless, Heaven's Gate

143 Stephen Bruce Mutch, Cultism, Terrorism, and Homeland Security, 5 CULTIC STUD. REV. 169, 173 (2006).

144 See id.; Arthur A. Dole, Are Terrorists Cultists?, 5 CUltiC STUD. REV. 198, 217

(2006) (“Are Terrorists cultists? In my opinion some, like Al Qaeda, certainly are.”).

145 Terra Manca, Innocent Murders? Abducted Children in the Lord's Resistance Army, 7 Cultic StUd. REV. 129, 130, 141-42 (2008).

146 Id.

147 See id. (citing United Nations' figures, however, other estimates are higher).

148 See id. at 130 .

149 See id.

150 See id. at 141-43.

151 An organization that claimed to have raised money and awareness about LRA was "Invisible Children." They have recently posted videos on YouTube explaining that they are no longer operating.

152 See Dole, supra note 144; Rodriguez-Carballeira et al., supra note 77, at 50.

153 See Dole, supra note 144, at 211. 
fit the characteristics of a cult because its members were "strongly attached to their leaders, who exerted exceptional psychological control." $" 154$

\section{Psychotherapy Cults}

Followers of psychotherapy cults espouse that their followers' devotion leads to greater intellectual enlightenment. ${ }^{155}$ These groups are profit-motivated centers run by the unskilled who do more harm than good. ${ }^{156}$

An example is the Sullivan Institute in Manhattan, New York, which was a community of middle-class artists and professionals who lived together in the 1970s and ' $80 \mathrm{~s}$ and engaged in unorthodox psychoanalytic therapy. ${ }^{157}$ The collective included an estimated 200 members who lived in three buildings on the Upper West Side and ran a political theater group in the East Village. ${ }^{158}$ Children were separated from parents. ${ }^{159}$ A former Sullivanian explained that the basic tenet of the teachings was that the nuclear family was the "root of all evil."160 Children were separated from their parents because it was preached that they should not have special bonds with their parents. ${ }^{161}$ Sexual promiscuity was strongly encouraged for adults and minors. ${ }^{162}$ As a former member explained, "[e]veryone, even the kids, was supposed to have as many 'dates' as possible. In one week, my son had dates with 23 different people. I didn't want him to live like that." 163 Married

\footnotetext{
154 Id.

155 See HASSAN, supra note 55 , at 86.

156 See id.

157 AMY B. Siskind -THE SUlLIVANIAN InSTITUTE/FourTH WALl COMMUNITY: THE RELATIONSHIP OF RADICAL INDIVIDUALISM AND AUTHORITARIANISM (Praeger: Westport, Conn. 2003); reviewed by Daniel Shaw, 5 CULTIC STUD. REV. 333 (2006).

158 See Margaret Thaler Singer, Maurice K. Temerlin \& Michael D. Langone, Psyschotherapy Cults, 7 CULTIC STUD. J.101-25 (1990).

159 See id.

160 Singer et al., supra note 158.

161 In the formative years of the community (1957 to 1970), the leadership advocated that their patients either send their children to boarding schools or hire full-time caregivers. In the later years (1971 to 1992), the Sullivanians reared children in communal households with one parent and a group of same-sex roommates. Young children were separated from their parents and spent most of their time with paid caregivers and other community children. Amy B. Siskind, Pathological Psychoanalysis: An Insider's View of the Sullivanian? Fourth Wall Psychotherapy Community, 5 InT'L J. CUltiC STUD. 45-51 (2014)

162 See Singer et al., supra note 158.

$163 \mathrm{Id}$.
} 
couples were encouraged to sleep with a different member of the opposite sex each night. ${ }^{164}$ Pyschotherapy cults can cause harm to the members' psyche. ${ }^{165}$

\section{Commercial Cults}

Commercial cults recruit with a promise of profit for the individual. ${ }^{166}$ Often the leaders build their organization around pyramid schemes that depend upon recruitment of people to sell and purchase wares. ${ }^{167}$ Their commercial product could be magazine subscriptions or any other goods. ${ }^{168}$ Their technique could be door-to-door sales or word-of-mouth. ${ }^{169}$ The destructive nature of this category of cults is in the leaders' treatment of the salespeople. ${ }^{170}$ The salespeople are often manipulated through fear, guilt, and sometimes physical and sexual abuse into selling products to the public to create revenue for the cult. ${ }^{171}$

\section{Cults and the Law}

Court cases reveal two legal impediments to prosecuting cult leaders and defending vulnerable adherents. First, U.S. law strongly protects religion. ${ }^{172}$ Second, U.S. evidence rules generally impair prosecutors' ability to introduce evidence of brainwashing and coercion. ${ }^{173}$

\section{U.S. Law Strongly Protects Religion}

In the United States, every person has the right to freely believe in and practice the religion of his or her choice. ${ }^{174}$ Furthermore, any religious group has the right to persuade and attract new members to its

164 See id

165 See id.

166 See HASSAN, supra note 55, at 87.

167 See id.

168 See id.

169 See id.

170 See id.

171 See id.

172 American jurisprudence stems from the constitutional tenet of free exercise of religion. U.S. CONST. amend. I.

173 See discussion infra.

174 U.S. Const. amend. I; see also Laura B. Brown, Note, He Who Controls the Mind Controls the Body: False Imprisonment, Religious Cults, and the Destruction of Volitional Capacity, 25 VAL. U. L. REV. 407, 410-11 (1991). 
ranks. ${ }^{175}$ This Constitutional right to freedom of religion has, at times, been misinterpreted. ${ }^{176}$

Although the First Amendment, which describes the freedom of religion, is laudable in its conception, deference to this constitutional right has impeded legal intervention when cults tilt towards destructiveness. ${ }^{177}$ An American court has professed, "[t]he right to the free exercise of religion unquestionably encompasses the right to preach, proselyte, and perform other similar religious functions." Courts have protected persons' freedom to practice their religion, as our Constitution provides, but at what cost? ${ }^{179}$ While defending religious liberty is a right that Americans should be proud to protect, the right to proselytize should have limits. Similarly, the right of religious leaders to preach to followers should be within the bounds of common dignity. ${ }^{180}$

As an illustration, former members of the Unification Church brought an action against the Church for fraud, false imprisonment, and intentional infliction of emotional distress. ${ }^{181}$ Although the court was sympathetic to claims of fraudulent inducement to join the Church, the court stopped short of granting the plaintiffs a remedy. ${ }^{182}$ In considering (in dicta) whether to criminalize brainwashing, the court found such a solution too "coercive" because it "could result in the jailing of church members" and "would clearly impose a greater burden on religion than would civil tort liability for fraud." 183

\footnotetext{
175 McDaniel v. Paty, 435 U.S. 618, 626 (1978); Brown, supra note 174.

176 See Marci A. Hamilton, God vs. the Gavel: The Perils of Extreme RELIGIOUS LiBERTy 18-21 (2d ed., Cambridge Univ. Press 2014).

177 See HASSAN, supra note 55, at 316.

178 McDaniel, 435 U.S. at 626.

179 See Scheflin, supra note 53, at 75.

180 See Michael D. Langone, Cults, Evangelicals, and the Ethics of Social Influence, 2 CUlTIC STUD. J. 371-88 (1985) (advocating that "evangelism, if practiced according to Christian tenets, should be ethical").

181 See Molko v. Holy Spirit Assn., 762 P.2d 46 (Cal. 1988), cert. denied, 109 S.Ct. 2110 (U.S. May 22, 1989).

182 See id ("A government action burdening free exercise, even though justified by a compelling state interest, is impermissible if any action imposing a lesser burden on religion would satisfy that interest.").

$183 \mathrm{Id}$. at 61 (Criminalizing brainwashing may not produce the best result, anyway. If the cult recruiter has also been subjected to brainwashing, then perhaps the remedy does not fit the target.).
} 


\section{U.S. Evidence Rules Generally Impair Prosecutors' Ability to Introduce Evidence of Brainwashing and Coercion}

The flip-side of prosecution also presents challenges. Those further down the command ladder of a cult have been unable to rely upon undue influence or brainwashing as a defense against prosecution for their criminal actions. ${ }^{184}$ For instance in 1974, Patty Hearst was captured by the cult known as the Symbionese Liberation Army (SLA). ${ }^{185}$ She was locked in a closet, starved, and raped. ${ }^{186}$ Eventually her captors wore her down, she became an SLA member, and she helped commit crimes perpetrated by the group. ${ }^{187}$ Hearst was ultimately arrested in connection with a bank robbery. ${ }^{188}$ At trial, her defense centered on the idea that she had been brainwashed and, thus, should not be held responsible for her actions. ${ }^{189}$ When she was captured, brainwashing became a popular topic of news stories. ${ }^{190}$ At her trial, the court, unconvinced that brainwashing was a reason to excuse her criminal acts, convicted and imprisoned her. ${ }^{191}$

In 1990, a defendant in a criminal case claimed to have been "brainwashed" by the cult of Scientology. ${ }^{192}$ The defendant tried to introduce evidence about the church's use of influence techniques as a defense to the government's theory that he possessed the requisite intent to commit fraud. ${ }^{193}$ The Fishman court applied the legal

184 See HASSAN, supra note 55, at 313 (blaming the American Civil Liberties Union for being on the wrong side of these litigations).

185 U.S. v. Hearst, 466 F. Supp. 1068, 1071 (N.D. Cal. 1978), aff'd in part, vacated in part, 638 F.2d 1190 (9th Cir. 1980).

186 See id.

187 See id.

188 See id.

189 See id.

190 See id

191 See HASSAN, supra note 55, at 84; United States v. Hearst, 412 F. Supp. 863, 870 (N.D. Cal. 1975) (the defense had argued "indicated that closely related to the anticipated defense of coercion will be the question of whether the defendant was subjected to such intense mental and psychological pressure by her captors as to have become 'brainwashed' by them and 'converted' to their cause.").

192 United States v. Fishman, 743 F. Supp. 713 (N.D. Cal. 1990).

193 Dr. Margaret Singer, a well-known forensic psychologist, and Dr. Richard Ofshe, a social psychologist, were expected to testify. Singer was to testify that "upon joining the Church of Scientology, defendant was subjected to intense suggestion procedures as well as other joining social and behavioral influence processes." Dr. Ofshe was expected to testify that "Scientology can induce a person to believe that they have the power to control mental matter, energy, space and time." Id. at 715 . 
standards of current rules of evidence, ${ }^{194}$ which come from the seminal case of Frye v. United States ${ }^{195}$ and United States v. Amaral. ${ }^{196}$ However, the trial court concluded that under existing precedent, the expert testimony could not be introduced in evidence. ${ }^{197}$

In 1993, the United States Supreme Court established a set of criteria for federal courts to follow when considering whether to admit expert testimony during a trial known as the "Daubert test."198 The Daubert test did not relax the rules on expert testimony. ${ }^{199}$ Put another way, in prosecuting someone lower on the cult ladder, the standards of Daubert would cause an undue influence defense to fail. The most challenging element of the Daubert test would be establishing that the expert testimony on brainwashing meets the criteria of general acceptance in the scientific community. ${ }^{200}$

For example, in a criminal fraud case against a former cultist, participation in a cult leader's illegal scheme was not excused by the court. ${ }^{201}$ The defendant, known as "Katie," was convicted and sentenced on fraud and conspiracy charges stemming from a scheme devised by the cult leader to take out education loans and turn the

194 Id. at 717 (citing Federal Rules of Evidence Rule 702, and explaining that pursuant to this rule, the proffered expert must have specialized knowledge).

195 Id. (citing Fry v. United States, 293 F. 1013, 1014 (D.C. Cir. 1923)).

196 Id. (citing United States v. Amaral, 488 F.2d 1148 (9th Cir. 1973)). In synthesizing Amaral with Frye and the Rules of Evidence, the Fishman court explained that the test is as follows "[f]or determining the admissibility of expert testimony from mental health professionals": "that expert testimony (1) comes from a qualified expert; (2) be of proper subject; (3) conform to a generally accepted explanatory theory; and (4) have probative value that exceeds its prejudicial effect." Id.

197 Id. at 721 . The Fishman court held that under the Frye test, it would not "permit any evidence in support of a diminished capacity defense." Id. The Fishman court explained as follows: "Frye holds that "while courts will go a long way in admitting expert testimony deduced from a well recognized scientific principle or discovery, the thing from which the deduction is made must be sufficiently established to have gained general acceptance in the particular field in which it belongs." (quoting Fry v. United States, 293 F. 1013, 1014 (D.C. Cir. 1923)).

198 See Scheflin, supra note 53, at 71 (citing Daubert v. Merrell Dow Pharmaceuticals, Inc., 509 U.S. 579 (1993)). The four-prong test is (a) Whether the expert's theory can be tested; (b) Whether the expert's theory has been supported by publication or peer review; (c) Whether the expert's theory has a known error rate; and (d) Whether the expert's theory is generally accepted in the relevant scientific community. Id.

199 See Scheflin, supra note 53, at 71 (citing Fishman, 743 F. Supp. at 713 (N.D. Ca. 1990)); Robidoux v. O’Brien, 643 F.3d 334 (1st Cir. 2011).

200 See Scheflin, supra note 53, at 71.

201 Lorna Goldberg, Influence of a Charismatic Antisocial Cult Leader: Psychotherapy with an Ex-Cultist Prosecuted for Criminal Behavior, 3 INT'L J. CULTIC STUD. 15 (2012). 
money over to the cult. ${ }^{202}$ Although she likely was psychologically coerced into committing the crime, that coercion was no defense.

The prosecution cannot rely on a psychological coercion theory to support its case either. United States v. Kozminski set the standard for many years to come. ${ }^{203}$ In that case, the defendants were charged with holding two mentally-challenged farm workers in involuntary servitude. ${ }^{204}$ The facts alleged were that the men worked seven days a week, often seventeen hours a day, for essentially no pay. ${ }^{205}$ The Government relied primarily upon the theory that defendants used psychological coercion to keep the men on the farm. ${ }^{206}$ The court held that the Government could not prove a violation of the defendants' constitutional rights based on this mental coercion alone; it also had to prove that defendants used or threatened to use physical or legal coercion, which the prosecution could not do. ${ }^{207}$

Successful prosecutions have utilized laws prohibiting certain illegal behaviors that religious organizations sometimes engage in as part of a religious service. ${ }^{208}$ For instance, where a religion included the ingestion of an illegal substance, peyote, in its ceremonial rituals, a court (in a decision often referred to as the "peyote case") upheld an administrative decision denying adherents unemployment benefits when they were terminated for work-related misconduct based on use of the drug. ${ }^{209}$ The freedom of religion protections in the constitution

202 See id. at 17.

203 United States v. Kozminski, 487 U.S. 931, 933 (1988), superseded by statute, Victims of Trafficking \& Violence Protection Act of 2000, infra. The Kozminski court held: "Since the [lower court's] jury instructions encompassed means of coercion other than actual or threatened physical or legal coercion, the instructions may have caused respondents to be convicted for conduct that does not violate [the statutes]. The convictions must therefore be reversed.” Kozminksi, 487 U.S. at 933. The Kozminski decision remained intact until the "TVPA expressly overturned the Supreme Court's narrow definition of 'involuntary servitude" Marley S. Weiss, Human Trafficking and Forced Labor: A Primer, 31 ABA J. LAB. \& EMP. L. 1, 31 (2015).

204 Kozminski, 487 U.S. at 934.

205 Id. at 935 .

206 Id.

207 Id. at 944.

208 See Employment Div. v. Smith, 494 U.S. 872 (1990), superseded by statute, Religious Land Use and Institutionalized Persons Act of 2000, Pub. L. No. 106-274, as recognized in Sossamon v. Texas, 563 U.S. 277(2011).

209 Id. 
did not extend to them for engaging in illegal activity. ${ }^{210}$ Behaviors such as stalking or rape are also avenues for litigation. ${ }^{211}$

In response to the "peyote case," Congress passed the federal Religious Freedom Restoration Act of 1993 ("RFRA"). ${ }^{212}$ By passing RFRA, Congress made it more difficult to prosecute behavior claimed to be a religious practice. ${ }^{213}$ Under it, courts were obligated to apply a more rigorous test (known as the "compelling interest" test) against the government when it defended laws such as the peyote restriction. ${ }^{214}$ Constitutional scholar Marci Hamilton claims that RFRA was "the most far-reaching statute in favor of religious entities in United States history." 215 The problem with this sweeping legislation, she argued, was that it provided "blind accommodation ... for dozens of religious groups - without asking whether disabling every law in the country might be a mistake." ${ }^{216}$ Hamilton's larger concern was that certain religious groups brought harm upon their members under the guise of religious freedom, which was not contemplated by our Founding Fathers, yet was sanctioned by RFRA. ${ }^{217}$

Eventually, the U.S. Supreme Court struck down RFRA, ${ }^{218}$ but Congress enacted Religious Land Use and Institutionalized Persons Act of 2000 ("RLUIPA") ${ }^{219}$ to amend and retain parts of the former legislation. ${ }^{220}$ RLUIPA focuses on land-use laws and makes it easier for religious landowners to get approval for zoning law changes, for

$210 I d$.

211 See Robin A. Boyle, Women, the Law, and Cults: Three Avenues of Legal Recourse - New Rape Laws, Violence Against Women Act, and Antistalking Laws, 15 CULTIC STUD. J. (1998).

21242 U.S.C. $§ 2000 b b$, bb-1 (2012) [hereinafter RFRA].

213 The "Congressional Findings" of the RFRA stated:

(4) in Employment Div. v. Smith. . . the Supreme Court virtually eliminated the requirement that the government justify burdens on religious exercise imposed by laws neutral toward religion; and (5) the compelling interest test as set forth in prior Federal court rulings is a workable test for striking sensible balances between religious liberty and competing prior governmental interests.

42 U.S.C. $\S 2000 \mathrm{bb}$.

214 See HAMILTON, supra note 176, at 18-21.

$215 \mathrm{Id}$. at 22.

216 Id.

217 See id. at $27-35$.

218 See City of Boerne v. Flores, 521 U.S. 507 (1997) (holding that RFRA exceeded enforcement powers of Congress).

219 Religious Land Use and Institutionalized Persons Act of 2000, 42 U.S.C. $\S \S 2000$ ccc-5.

220 Id. 
example. ${ }^{221}$ One of the many problems with this legislation, Hamilton claims, is that mega churches have taken advantage of the zoning laws and built extensively in communities, draining resources for others. ${ }^{222}$

Successful prosecutions have more frequently occurred in extreme cases where there was evidence of physical abuse, torture, and murder, so proving psychological coercion was not required in order to show criminal liability. For instance, Paul Schaefer, leader of the cult formerly known as "Colonia Dignidad" (now called "Villa Baviera"), was found guilty of sexually abusing twenty-five children and sentenced to twenty years in prison. ${ }^{223} \mathrm{He}$ was ordered to pay $\$ 1.4$ million to his victims. ${ }^{224}$ When Augusto Pinochet came to power in Chile, his regime used Schaefer's compound as a torture center, subjecting victims to brainwashing, electric shock, tranquilizers, and isolation. ${ }^{225}$ While serving his sexual abuse sentence, Schaefer was also sentenced to seven years for a murder committed while he operated Colonia Dignidad. ${ }^{226}$

In another extreme case, a Norwegian father of thirteen children and adherent of the "Smiths Friends Christian Community" was sentenced to four months in prison for physically abusing his children by flogging them with coat hangers, lamp cables, yardsticks and birch rods over a fourteen-year period. ${ }^{227}$

On the civil side in the United States, former cult members have initiated suits based upon the wrongs done to them. Recognizing the difficulty of asserting undue influence, plaintiffs base these lawsuits upon grounds of lost wages, conversion of property and money, and psychological harm caused by the group's programs. ${ }^{228}$ Such lawsuits have been brought against the Church of Scientology, Transcendental Meditation-Ex, Werner Erhard for EST, and John Hanley for Lifespring. ${ }^{229}$

\footnotetext{
221 HAMILTON, supra note 176, at 188.

222 Id. at $123-26$.

223 See discussion supra notes 88-108 and accompanying text.

224 See News Summaries, 5 CUltic StUd. REV. 308 (2006).

225 See id. at 416.

226 See News Summaries, 8 Cultic STUd. Rev. 88 (2009).

227 See News Summaries, supra note 224, at 321-22.

228 See HASSAN, supra note 55.

229 Id.
} 
A legal process used by youth who are nearing the age of majority and are trying to escape cults is to declare emancipation. ${ }^{230}$ Youth who manage to escape cults can seek the assistance of U.S. laws to become legally emancipated. ${ }^{231}$ FLDS youth have taken advantage of state laws that allow sixteen and seventeen-year-olds to petition juvenile courts for emancipation from their parents. ${ }^{232}$

Despite some successful criminal and civil lawsuits in the United States and abroad, the law does not go far enough to deal with cults that are so highly destructive. In the Jonestown tragedy, over 900 people were killed. ${ }^{233}$ There were group suicides at the "Branch Davidian" compound in Waco, Texas, in 1992 and "Heaven's Gate" in the 1990s. ${ }^{234}$ The "Order of the Solar Temple," geographically dispersed from Canada, Switzerland, to France, killed a total of seventy-four people in brutal and ritual deaths between 1994 and 1997. ${ }^{235}$ In 2000, more than 400 members of "The Movement for the Restoration of the 10 Commandments" were brutally murdered. Another 300 or more were burned to death in a locked church building in Uganda. ${ }^{236}$

Our current legal system seems inept with respect to prosecution of cult leaders. As I wrote in an article for the Cultic Studies Journal back in 1998, "[t]here are no [U.S.] state or federal laws that prohibit cults. ${ }^{237}$ In that article, I described criminal statutes pertaining to rape, Violence Against Women Act, and anti-stalking laws. Today, trafficking laws provide an additional avenue for prosecution.

\section{II}

\section{HUMAN TRAFFICKING}

It is difficult to calculate the number of people trafficked around the world because it is a hidden crime. Unlike slavery of the American

230 See Robin A. Boyle, How Children in Cults May Use Emancipation Laws to Free Themselves, 16 CULTIC STUD. J. 1 (1999) [hereinafter Emancipation].

231 See id.

232 See News Summaries, supra note 224. Some countries have clamped down with more restrictions after 9/11. In Australia, legislation now designates religious groups as "terrorist" and bans them. Membership in these prohibited groups is met with punishment. Harsher security laws trump other rights. Mutch, supra note 143, at 189.

233 See Robert S. Baron, Arousal, Capacity, and Intense Indoctrination, 18 CULTIC STUD. J. 172, 173 (2001).

234 See id. at 173.

235 See Violent Outcomes, supra note 1, at 287.

236 See id. at 288.

237 Boyle, supra note 211 , at 1. 
south before the Civil War, when plantations and slaves were out in the open and could be counted, today's enslavement is clandestine. At any given time, as many as 27 million people around the globe are victims of human trafficking. ${ }^{238}$ Where are trafficked victims? Anywhere and everywhere. They could be in any country and in any state of America. ${ }^{239}$ There is indication that they are in "mines in the Democratic Republic of the Congo, fishing vessels off the coast of New Zealand, garment factories in Jordan, the forests of Brazil, carpet factories in Nepal, agricultural fields in Florida, and everywhere in between." 240 Traffickers and their victims continue to elude authorities. Less than one percent, or one victim for every 2000, has been identified. $^{241}$

\section{A. Laws Prohibiting Human Trafficking}

\section{International Laws}

How is human trafficking defined? An accepted international definition of human trafficking is broad and is provided in the Protocol to Prevent, Suppress and Punish Trafficking in Persons, Especially Women and Children:

[T] he recruitment, transportation, transfer, harbouring (sic) or receipt of persons, by means of the threat or use of force or other forms of coercion, of abduction, of fraud, of deception, of the abuse of power or of a position of vulnerability or of the giving or receiving of payments or benefits to achieve the consent of a person having control over another person, for the purpose of exploitation. ${ }^{242}$

The Protocol defines "exploitation" as "the prostitution of others or other forms of sexual exploitation, forced labour (sic) or services,

238 U.S. DEP'T OF STATE, TRAFFICKING IN PERSONS REPORT (2013).

239 See UNICEF, http://www.unicefusa.org/mission/protect/trafficking/end (last visited May 10, 2016).

240 Kelly Hyland \& Kavitha SReeharsha, Freedom for All: An AtTorney's GUIDE TO FIGHTING HUMAN TRAFFICKING 1 (ABA 2015).

241 See id. at 2.

242 U.N. High Commissioner for Human Rights, Protocol to Prevent, Suppress and Punish Trafficking in Persons, Especially Women and Children, Supplementing the United Nations Convention Against Transnational Organized Crime, art. 3(a), U.N. Doc. 55/25 (Nov. 15, 2000), http://www.ohchr.org/EN/ProfessionalInterest/Pages/ProtocolTrafficking In ersons.aspx (last visited on May 10, 2016). 
slavery or practices similar to slavery, servitude or the removal of organs." 243

While sex trafficking is what comes to mind when discussing human trafficking, there are several other categories of trafficking, as our international and federal laws provide protections against the following: ${ }^{244}$ workplace labor, ${ }^{245}$ domestic servitude, ${ }^{246}$ debt servitude, ${ }^{247}$ and child soldiering. ${ }^{248}$ Also criminalized are acts involving child sexual exploitation, forced marriage, servile forms of marriage, child marriage, and forced prostitution. ${ }^{249}$

\section{Protections for Trafficking Victims Under International Law}

Trafficking victims, therefore, have rights under international law. ${ }^{250}$ Further protections are given to child victims of trafficking, such as rules and obligations specified in the Convention on the Right of the Child which provides that "the best interests of the child are to be at all times paramount." ${ }^{251}$ According to the Convention, children trafficked from other countries are to be given the same legal protections as nationals, including rights to privacy and physical and moral integrity. ${ }^{252}$ Privacy rights are particularly important to trafficked victims to prevent further humiliation and harm. ${ }^{253}$

\footnotetext{
243 Id.

244 See HYLAND \& SREEHARSHA, supra note 240, at 11.

245 In trafficked workplace labor, fear is imposed upon workers causing them to fear leaving.

246 In domestic servitude, workers are forced to provide cleaning of the home, cooking, and childcare.

247 In debt servitude, traffickers use an alleged debt to force victims into labor, often the debt is incurred through emigration.

248 In child soldiering, youth are recruited to fight for armed causes.

249 U.N. Human Rights OfFiCE OF THE High COMMISSIONER, Human Rights and Human Trafficking: Fact Sheet No. 36 (last visited May 10, 2016) [hereinafter U.N. Fact Sheet No. 36].

250 See id. at 6 .

251 See id. at 7. The Convention on the Rights of the Child has not been ratified by the United States, despite it being the most widely ratified human rights treaty in history. UNICEF, http://www.unicef.org/crc/index_73549.html (last visited July 12, 2016).

252 See id.

253 Similar provisions for trafficked children are provided elsewhere-such as The Protocol and Convention on Action against Trafficking in Human Beings. See U.N. Fact Sheet No. 36, supra note 249, at 7.
} 


\section{Legal Effect of the International Treaties}

What is the effect of international treaties? Countries (referred to as "States") that are signatories to the treaties are obligated to conform their national legislation to those of the international law, staying consistent with the standards of the international treaty. ${ }^{254}$ Designated international courts all have enforcement power making signatories accountable. ${ }^{255}$ There are related treaties that can be used to combat and prevent trafficking. ${ }^{256}$

Also significant, human rights treaties contain substantive reference to trafficking. ${ }^{257}$ International community organizations recognize the need to prevent and combat trafficking and provide protections to victims. $^{258}$

Decisions from legal cases of international tribunals can serve as a source of legal authority by U.S courts. ${ }^{259}$ The European Court of Human Rights:

affirmed that States are required to "take such steps as are necessary and available in order to secure relevant evidence, whether or not it is located in the territory of the investigating State" and that "in addition to the obligation to conduct a domestic investigation into events occurring on their own territories, member States are also subject to a duty in cross-border trafficking cases to cooperate effectively with the relevant authorities of other States concerned in the investigation of events which occurred outside their territories. $" 260$

There are influential documents that do not have enforcement power, but nevertheless help form the international legal framework. Examples include the guidelines on child trafficking issued by the

254 Id.

255 See id. at 9.

256 See id. (examples include: the United Nations Convention against Transnational Organized Crime, the United Nations Convention against Corruption, and the Rome Statute of the International Criminal Court).

257 See id. at 5 (The treaties are (1) the Convention on the Elimination of All Forms of Discrimination against Women (art. 6), and (2) the Convention on the Rights of the Child (art. 35).).

258 See id. ((1) Council of Europe's Convention on Action against Trafficking in Human Beings, and (2) the European Union Directive. Also the United Nations General Assembly and the Human Rights Council have affirmed that trafficking violates and impairs fundamental human rights.).

259 Id. at 9, 13 (citing Rantsev v. Cyprus and Russia, decided by the European Court of Human Rights, Application No. 25965/04, Judgement of January 7, 2010, para. 286).

$260 \mathrm{Id}$. at 13. 
United Nations Children's Fund (UNICEF) and those on trafficking and asylum issued by the Office of the United Nations High Commissioner for Refugees (UNHCR). ${ }^{261}$ These guidelines can serve as persuasive authority for legislation and models for best practices in combating trafficking.

\section{United States Laws Prohibiting Human Trafficking}

In 2000, the U.S. Congress reacted to human rights abuses by passing the Victims of Trafficking and Violence Protection Act (TVPA) ${ }^{262}$ The goals of the federal legislation in the United States are similar to those of the international laws. The purpose of the TVPA was to "combat trafficking in persons." 263 Since 2000, the TVPA was reauthorized by Congress four times. ${ }^{264}$ Like international law, there are essentially two categories of crimes affected by this legislation: sex trafficking and labor. ${ }^{265}$

In addition to the federal statute, the Obama Administration, announcing a plan to coordinate U.S. federal agencies, denounced trafficking by stating that "[h]uman trafficking is a denial of our common humanity and an affront to our ideals as Americans." ${ }^{266}$ The Obama Administration declared human trafficking "a crime that involves the exploitation of a person for the purpose of compelled labor or a commercial sex act." ${ }^{" 267}$ The aim of the federal legislation was tri-

\footnotetext{
261 Id. at 10.
}

262 Victims of Trafficking \& Violence Protection Act of 2000, Pub. L. No. 106-386, 114 Stat. 1464 (2000) (codified as amended in various titles of U.S.C.). The Act is comprised of three divisions-(i) the Trafficking Victims Protection Act of 2000, 22 U.S.C. $\S \S$ $7101-7110$ (2000), (ii) Violence Against Women Act of 2000, 42 U.S.C.A. $§ 13981$ (West 2015), and the trafficking sections begin with $\S 14044$ et. seq. (Combat Human Trafficking Act) and (iii) Miscellaneous Provisions, 18 U.S.C.A. § 1596 and "Sex Trafficking of Children or by Force, Fraud, or Coercion," 18 U.S.C.A. § 1591.

263 Aguirre v. Best Care Agency, Inc., 961 F. Supp. 2d 427, 459 (E.D.N.Y. 2013) (quoting H.R. Conf. Rep. No. 106-939, at 3 (2000)).

264 See Federal Strategic Action Plan on Services for Victims of Human Trafficking in the United States, Coordination, Collaboration, Capacity, at 5 (2013-2017) [hereinafter Federal Action Plan]. Congress supported the goals of the legislation by reauthorizing it in 2003, 2005, 2008, and 2013. Id. Bills are pending in Congress now for approval. Currently up for reauthorization is the Runaway and Homeless Youth and Trafficking Prevention Act, 42 U.S.C. $\S 5701$ et seq., which expired in September 2013. The purpose of the federal statute is to provide shelter and services to runaway youth. Bills S. 262 and H.R. 1779 are under consideration. See generally UNICEF, https://www.unicefusa.org(last visited Apr. 23, 2015).

265 See Federal Action Plan, supra note 264, at 5.

266 Id. at 5.

267 Id. 
fold: prevention, protection, and prosecution. ${ }^{268}$ The Obama Administration adds to the so-called "3 'p's" a fourth goal: partnership. $^{269}$

On the federal level, prosecution for trafficking is coordinated by the Human Trafficking Prosecution Unit of Department of Justice's (DOJ) Civil Rights Division. ${ }^{270}$ The DOJ provides technical assistance with coordinates with the U.S. Attorney's Offices. ${ }^{271}$ Individual U.S. states have also enacted their own statutes for protecting trafficked persons. ${ }^{272}$

Worldwide, it is estimated that approximately 4,000 traffickers are convicted every year, but only 138 were convicted federally in the United States, and this was from the sex industry. ${ }^{273}$ The United States is missing a large percentage of labor traffickers. ${ }^{274}$

\section{How U.S. Federal Law Is Changing}

The Federal trafficking statutes can be used to expand the remedies available to cult victims and to prosecutors seeking to hold cult leaders accountable for their criminal acts. Remedies are no longer limited to those of the federal case of Kozminski, as discussed above, because courts have expanded the breadth of what constitutes forced labor in reliance upon the TVPA. Section 1589 of the TVPA provides:

(a) Whoever knowingly provides or obtains the labor or services of a person by any one of, or by any combination of, the following means ...

(3) by means of the abuse or threatened abuse of law or legal process; or

268 See HYLAND \& SREEHARSHA, supra note 240, at 3.

269 See Federal Action Plan, supra note 264, at 5.

270 HYLAND \& SREEHARSHA, supra note 240, at 39.

271 Id. at 41.

272 For instance, in New York State, trafficked victims convicted of prostitution are permitted to move to vacate the judgment pursuant to Criminal Procedure Law $\S 440.10$ (i). The New York State Legislature updated this statutory provision when it passed the Trafficking Victims Protection and Justice Act in 2015. For further information, go to http://www.nysenate.gov/legislation/bills/2015/s7 (last visited on May 10, 2015). See also New Report on Remedies for Criminalized Human Trafficking Victims Released, CUNY SCHOOL OF LAW (Feb. 24, 2014), www.cuny.edu/mu/law/2014/02/24/new-report-on -remedies-for-criminalized-human-trafficking-victims-released. (last visited on May 10, 2016).

273 See Hyland \& SREEHARSHA, supra note 240, at 3-4.

274 See id. at 4. 
(4) by means of any scheme, plan, or pattern intended to cause the person to believe that, if that person did not perform such labor or services, that person or another person would suffer serious harm or physical restraint. ${ }^{275}$

For instance, teachers who came from the Philippines to work in the United States filed actions against a teacher recruiting service alleging fraud and violations of TVPA and other criminal laws. ${ }^{276}$ Plaintiffs argued that they paid steep recruitment fees in order to teach in the United States and that they were induced by fraud and verbal threats. ${ }^{277}$ The defendants argued that the human trafficking statutes did not apply to teachers, and, instead, were meant only to apply to those in the sex trade or other forms of nonprofessional labor. ${ }^{278}$ The court disagreed. ${ }^{279}$ In relying upon the TVPA, the court reasoned that the "TVPA not only protects victims from the most heinous human trafficking crimes, but also various additional types of fraud and extortion leading to forced labor." 280

In another case, Menocal v. GEO Group, Inc., detainees at a forprofit immigration detention facility brought an action against the facility for their meager compensation in the Voluntary Work Program. ${ }^{281}$ They were performing menial jobs without compensation and were held under threat of solitary confinement. ${ }^{282}$ Citing the TVPA (among other statutes), the plaintiffs alleged that by requiring them to perform manual labor under threats, defendants knowingly provided or obtained the "labor or services of a person ... by means of force, threats

27518 U.S.C.A. Sec. 1589 (2015). Furthermore, section 1589 (c) (1) provides:

The term "abuse or threatened abuse of law or legal process" means the use or threatened use of a law or legal process, whether administrative, civil, or criminal, in any manner or for any purpose for which the law was not designed, in order to exert pressure on another person to cause that person to take some action or refrain from taking some action.

The term "serious harm" means any harm, whether physical or nonphysical, including psychological, financial, or reputational harm, that is sufficiently serious, under all the surrounding circumstances, to compel a reasonable person of the same background and in the same circumstances to perform or to continue performing labor or services in order to avoid incurring that harm.

276 Nunag-Tanedo v. East Baton Rouge Parish School Bd, 790 F. Supp. 2d 1134 (C.D.

Cal. 2011)

277 Id. at $1143-44$.

278 Id. at 1144 .

279 Id. at 1146.

280 See id. at 1143 (holding that under 18 U.S.C. Sec. 1589 plaintiffs sufficiently alleged that defendants violated the TVPA).

281 Menocal v.GEO Group, Inc., 113 F. Supp. 3d 1125 (D. Colo. July 6, 2015).

282 Id. 
of force, physical restraint, or threats of physical restraint."283 Defendants argued that the TVPA was intended to apply to trafficking persons for labor and/or sex. ${ }^{284}$ In holding for the plaintiffs, the court reasoned that the language at issue under the TVPA is "broader than the language at issue in Kozminski" and other cases. ${ }^{285}$

In synthesizing case holdings, courts are employing an expansive view of the rights of victims under the TVPA to seek justice. The evolving case law pertaining to the U.S. federal trafficking statutes opens the door for potential litigation strategy in cases seeking justice for the ills of cults.

\section{B. Cults Compared with Human Trafficking Rings}

Cultic organizations and trafficking rings have much in common. Much like cult adherents, trafficked victims are threatened by their traffickers with serious consequences should they escape and seek help. ${ }^{286}$ Not all trafficked persons live in isolation, ${ }^{287}$ but, much like those living under the undue influence exhibited in cults, trafficked persons are fearful of reaching out for help. ${ }^{288}$

\section{Physical Force, Threats, Malnourishment}

Both cult leaders and traffickers use actual physical assaults, including beatings, stabbings, burnings, and sexual abuse, ${ }^{289}$ to maintain control over their victims. Traffickers are known to threaten harm as well, both by making direct threats to victim and his or her family, ${ }^{290}$ and by inflicting harm on others in the victim's presence. ${ }^{291}$ Similarly, as was illustrated above by the story of Elissa Wall - who was threatened with an altar ritual that would result in her death for having had an adulterous affair and leaving her husband-cult adherents are subjected to threats of violence in various ways.

283 Id. at 1133 (citing 18 U.S.C. $§ 1589$ (a). Section 1595 provides the civil remedy.).

$284 \mathrm{Id}$. at 1132.

$285 \mathrm{Id}$. at 1133.

286 HYLAND \& SREEHARSHA, supra note 240, at 3.

287 Id.

288 Id.

289 See id. at 22-23; Ian Urbina, Forced Labor for Cheap Fish: 'Sea Slaves' Endure Danger and Debt Trawling for Pet Food, N.Y. TIMES, July 27, 2015, at A1 (describing a first-hand account of kidnapping, captivity, violence).

290 See HYLAND \& SREEHARSHA, supra note 240, at 23.

291 Id. 
Malnourishment is common among both trafficked persons ${ }^{292}$ and cult members. Traffickers withhold food as a form of punishment. ${ }^{293}$ For example, some trafficked factory workers have reported subsisting on broth and rice for a year, and domestic workers have had nutritional meals withheld entirely. ${ }^{294}$ Similarly, cult adherents are, at times, pressured to forgo nutrition. For example, members of the isolationist group "The Body" pressured a member to take her infant son (who also happened to be the child of the cult's leader) off of solid food and formula and sustain him on breast milk only. ${ }^{295}$ Sadly, the mother could not produce adequate milk and the child died of malnutrition before turning a year old. ${ }^{296}$

\section{Psychological Coercion and Surveillance}

Bonding and dependency, the twisted result of an abusive relationship, is common among both cultic and trafficked victims. " $[\mathrm{P}]$ sychological coercion has proven to be just as powerful as physical force and used more often, creating invisible barriers to a trafficked person's escape." 297 Persons lured to their traffickers through fake romantic relationships have continued to remain loyal despite the illegality of trafficking. ${ }^{298}$ Similarly, FLDS member Wall explained that her fellow church members lied at trial to defend the church, despite the widespread practice of forced marriage to underage teenage girls. ${ }^{299}$

One result of psychological coercion is that victims may say things or exhibit behaviors that, perpetrators can argue, signal their consent to their circumstances. In trafficking cases, international human rights law has recognized that one cannot consent to having his or her freedom taken away. ${ }^{300}$ Thus, the prosecution can use these laws to attack a victim's expressions of consent, especially if the victim's freedom was obviously restricted (for example, through locked doors or shackles). However, alleged "consent" of cult devotees is often a more challenging hurdle for prosecutors. While the law recognizes that one

\footnotetext{
$292 I d$. at 24.

293 Id.

294 Id.

295 HAMILTON, supra note 176 , at $72-73$.

296 Id.

297 HYLAND \& SREEHARSHA, supra note 240, at 26.

298 Id. at 30.

299 See WALL, supra note 20.

300 See U.N. Fact Sheet No. 36, supra note 249, at 3-4.
} 
cannot consent to physical and mental abuse in most cases, cult leaders may argue for a different understanding of consent when the "abuse" is part of an allegedly religious belief. Because of the protection and deference afforded to religious freedoms and freedom of expression inside and outside of the United States, these arguments may resonate with the courts. Further, cult leaders can point to the voluntary nature of joining a cult in the first place. Often, ex-cultists later claim that they could not have, in the legal sense, consented to joining the cultic group because they were uninformed about its tactics when they were considering membership, and thus could not make an informed choice. Yet, this can be a difficult argument to make, particularly if visible physical restraints, like those observed in trafficking cases, did not limit the member's ability to leave the group.

Much like cult adherents, trafficked persons are under surveillance. Traffickers watch their captives through video cameras in massage parlors, through human watch as armed guards around a work site, and by other means. ${ }^{301}$

\section{Labor and Profit Motives}

Both traffickers and cult leaders are known to exploit their victims for profit. Labor traffickers, for example, may force their victims to endure up to eighteen-hour workdays, often under grueling conditions, only to have their earnings taken by the trafficker at the end of the day. ${ }^{302}$ Sex traffickers force their victims to engage in sexual activities for the trafficker's income. ${ }^{303}$ Harsh conditions can be inflicted as punishment for those who are noncompliant with the rules. ${ }^{304}$ Similarly, cults need to survive somehow and leaders often rely upon the labor of followers, including the children. ${ }^{305}$ Some cults run businesses as a means of income, such as the pyramid schemes described above. ${ }^{306}$

Both traffickers and cult leaders also use economics to coerce their victims. For example, traffickers may overcharge a person for something (such as passage to the United States), such that the person

\footnotetext{
301 See HYLAND \& SREEHARSHA, supra note 240, at 23.

302 Id. at 24.

$303 \mathrm{Id}$. at 23.

304 Id. at 24.

305 See HASSAN, supra note 40.

306 Id.
} 
is left with a debt to the trafficker that is impossible to pay down and requires the person to remain under the trafficker's control. ${ }^{307}$ Similarly, cult victims may have turned over mortgages and life savings to their ringleaders, such that they do not feel they can afford to leave the group. ${ }^{308}$

Viewed more broadly, cults and trafficking rings are similar in that they both function as businesses. When the dogma of cults is stripped away, it is clear that their leaders run a business - whether it is a church in a U.S. rural or urban town, ${ }^{309}$ a Jonestown in a developing country that housed a 1,000 people, ${ }^{310}$ or an overcrowded apartment in Manhattan $^{311}$ _just like traffickers run a business. Cults are organizations that must be managed; their members are fed and sheltered, have jobs, and provide some form of education for their young. ${ }^{312}$ The devotee, in some way, contributes to the economic functioning of the cult. ${ }^{313}$ As one former cultist expressed:

I now understand that I was used as a tool to serve the leader's need for increased membership and therefore increased income. I was in a community that valued spirituality over materialism with double standards. As 'co-workers,' most of us lived very modestly, giving whatever we could to support the leader's lifestyle. ${ }^{314}$

\section{Fraudulent Recruitment}

The tactics of traffickers are much like those of cult recruiters. Both use fraud as a recruitment tool to deceive their target. Some traffickers lure in victims with the pretense of a friendship, romance, or mentorship, but the end result could be a prostitution ring. ${ }^{315}$ Some traffickers promise jobs and assistance with emigration to another town or country; sometimes traffickers even seal their alleged agreement in writing or by verbal contract. ${ }^{316}$ Traffickers use traditional forms of

\footnotetext{
307 HYLAND \& SREEHARSHA, supra note 240, at 29-30.

308 See id. at 41.

309 See Emancipation, supra note 230. When interviewing subjects for that article, the religious cults were described by the former members as businesses.

310 See supra Part I.

311 See supra Part I.

312 See supra Part I.

313 See supra Part I.

314 Colleen Russell, Touched: Disconfirming Pathogenic Beliefs of Thought Reform Through the Process of Acting, 9 INT'L CULTIC SUTD. ASS'N 106, 112 (2010) (recollecting Eckankar in Southern California).

315 HYLAND \& SREEHARSHA, supra note 240, at 25.

316 Id. at 24.
} 
publicity such as ads in the newspaper or other promotions and wordof-mouth. ${ }^{317}$ What trafficked victims are not told, however, is that traffickers may have created false identifications for them which can later be used to coerce the victims (who fear the trafficker will report the false identification to authorities). ${ }^{318}$ Trafficked victims are also not told that their traffickers may withhold their true passports once they have emigrated. ${ }^{319}$ And, of course, trafficked persons are not told of the abuse they are likely to face if they are being trafficked for labor or sex, for example.

Just as traffickers have posed as boyfriend/girlfriends or parental figures to entice persons into their ring, cults may use flirtation and sex as lures. For instance, in the cult known as "Children of God," recruiters attracted new members using a technique called "flirty fishing. ${ }^{, 320}$ Flirty fishing involved using young members as prostitutes to entice others to join the group. ${ }^{321}$ Another technique, known as "love bombing," involves "an exchange of affection (verbally and through smiles) that failed to express genuine intimacy or connection to others." 322

Both traffickers and cult leaders rely on the Internet to fraudulently recruit members. The Internet is the "latest hot spot for promoting global trafficking and recruitment of women and children." 323 It is especially used to advertise "businesses" offering women and girls as brides for marriage; these "businesses" are actually sex trafficking operations in disguise. ${ }^{324}$ Analogously, some cults have used the

317 Id.; Ellen Barry, A Town Where Human Trafficking Corrupts All, N.Y. TIMES, July 24,2015 , at A1 (describing a "predatory operation of considerable scale" where traffickers use high-pressure tactics in a pyramid scheme).

318 HYLAND \& SREEHARSHA, supra note 240, at 26.

319 Id. at $24-25,26$.

320 Miriam Williams Boeri \& Karen Pressley, Creativity and Cults from Sociological and Communication Perspectives: The Processes Involved in the Birth of a Secret Creative Self, 9 CUltic StUd. ReV.173, 192 (2010); Christina Arnold, Human Trafficking as a Commercial Cult Mind Control Phenomenon, VIMEO (July 5, 2014) (vimeo.com/102628 104) (presenting on abuses in Children of God). Arnold is the Founder/Board President of Preventhumantrafficking.org.

321 See James D. Chancellor, A Response to Perry Bulwer's Evaluation of 'Life in the Family,' 6 CUlTiC STUD. ReV. 160, 162 (2007).

322 See Russell, supra note 314, at 113 (quoting Loomis).

323 Susan Tiefenbrun, The Saga of Susannah A U.S. Remedy for Sex Trafficking in Women: The Victims of Trafficking and Violence Protection Act of 2000, 2002 UTAH L. REV. 107, 119 (2002).

324 Id. 
internet to attract followers. Members of Heaven's Gate, for example, lured followers by broadcasting their apocalyptic doctrine over the Internet. ${ }^{325}$ The doctrine advised listeners to leave the earth via a spacecraft behind the comet Haley-Bopp. ${ }^{326}$ Their details of intending suicide were so specific that another individual not living in their compound committed suicide by following their web-based instructions to "exit." 327

\section{Isolation}

Both traffickers and cultic organizations use physical and psychological isolation as a tactic for controlling their victims. Traffickers restrict communication between their victims and victims' families, and they physically segregate their victims in living and working quarters that are apart from mass society. ${ }^{328}$ Cult researchers believe that some destructive cults continue to exist in isolated communities, likely depriving children and adults of their basic human rights. ${ }^{329}$ Often, cults are physically set apart from society; they may be geographically separated in a rural area or, if located inside an urban area, the adherents live in close proximity to one another and are coached not to interact with non-member neighbors. ${ }^{330}$ Cult members are often told not to associate with nonmembers, particularly family members who are not part of the cult. ${ }^{331}$ This isolation distances the member from the outside world and makes it easier for him or her to be controlled. ${ }^{332}$

\section{Shaming Tactics}

Both traffickers and cults may gain control of their victims by shaming. Trafficked individuals are threatened with exposure back home of the forced sex acts they have performed or the lack of money they have produced. ${ }^{33}$ Taking advantage of the pride of the individual,

325 Luis Santamaria del Rio, The Internet as a New Place for Sects, 7 CUlTIC STUD. REV. 20,23 (2008).

$326 I d$.

327 Id.

328 See HYLAND \& SREEHARSHA, supra note 240, at 28.

329 See Bulwer, supra note 79, at 144 (referring The Family); Arnold, supra note 320 (describing how she was isolated and had no money, but wanted to "get out" of her cult).

330 Telephone Interview with Mike Kropveld, supra note 96.

331 Id.

332 Id.

333 See Hyland \& SREeHARSHA, supra note 240, at 27-28. 
traffickers exploit this vulnerability by threatening to shame them at home. ${ }^{334}$ Traffickers have resorted to blackmail, threatening to send video or photographs home. ${ }^{335}$ Similarly, cults have publicly humiliated their members to set examples of behavior. ${ }^{336}$

\section{Human Trafficking as Distinguishable from Other Crimes}

Human trafficking can easily be confused with related crimes. It is important to understand that the crux of the crime of human trafficking is not the transportation of persons, but the use of force to obtain labor or service of a person. ${ }^{337}$ Unlike other crimes that require the offender to take the victim across a jurisdictional border (for example, from one state within the United States to another, or from one country to another), the international definition of human trafficking does not require a cross-border transgression. ${ }^{338}$ In fact, "[g]lobally, 29 percent of trafficked persons are enslaved in the area where they normally reside." $" 339$

Nor is human trafficking the same as migrant smuggling, although traffickers can be charged with smuggling. Again, central to the crime of trafficking is what happened once the victims were enslaved. Thus, smuggling, though also a crime involving deceitful transport, is not the same thing as trafficking. ${ }^{340}$

Trafficking is also distinguishable from prostitution. Prostitution, whether legal or not in its jurisdiction, is viewed as a consensual act between adults. ${ }^{341}$ Sex trafficking, in contrast, is forced prostitution by an unwilling member. ${ }^{342}$

Finally, trafficking is not the same thing as child labor. Sadly, some countries outside of the United States do not have laws that protect children from working as laborers in dangerous conditions. ${ }^{343}$ Families

\footnotetext{
334 See id. at 28.

335 Id.

336 See Bulwer, supra note 79 (discussion re: Berg and Merry).

337 See HYLAND \& SREEHARSHA, supra note 240, at 31.

338 See U.N. Fact Sheet No. 36, supra note 249, at 3.

339 HyLAND \& SREeHARSHA, supra note 240, at 31 (citing Int'l Labour Org., Global Estimate of Forced Labour (2012)).

340 See Hyland \& SREeHARSHA, supra note 240, at 31; U.N. Fact Sheet 36, supra note 249 , at 3 .

341 U.N. Fact Sheet 36, supra note 249, at 41.

342 See Hyland \& SREEHARSHA, supra note 240, at 31.

343 See id. at 32.
} 
that have their children work in impoverished countries for low wage and for long hours in harmful conditions fall outside of what is considered trafficking. ${ }^{344}$

\section{III}

\section{USING HUMAN TRAFFICKING STRATEgIES TO COMBAT DESTRUCTIVE CULTS}

Despite legislation, a high number of trafficking victims go undetected and evade authorities, ${ }^{345}$ as do cults victims and their leaders. Critics complain that not enough resources have been expended to prosecute human traffickers, rendering the laws ineffective. ${ }^{346}$ Significant resources and effort should be devoted to preventing and combating both traffickers and cults.

\section{A. Applying Criminal Trafficking Statutes to Prosecute Cult Leaders}

Depending upon the criminal acts perpetrated by the cult leader, conceivably various statutory sections of the trafficking laws would be violated. ${ }^{347}$ For instance, cults that rely on sex to recruit new members may be committing illegal "commercial sex acts" which are defined in the anti-trafficking statute as "any sex act on account of which anything of value is given to or received by any person." ${ }^{448}$ The phrase "anything of value" could translate to the cult context if that phrase is read as encompassing a broad range of benefits brought to a cult through sexual exploitation of its adherents to recruit new members.

The provisions that protect children from sex trafficking provide, in relevant part, that a person may not "knowingly. . . . (2) benefit[] financially or by receiving anything of value, from participation in a venture which has engaged in an act described in violation of paragraph (1)," 349 which, in turn, prohibits transporting, but also recruiting,

\footnotetext{
344 See id.

345 See id. at 38.

346 See Tiefenbrun, supra note 323.

347 See, e.g., 18 U.S.C. $\S 1589$ (a), an omnibus provision prohibiting forced labor, and other provisions of TVPA, discussed infra.

34822 U.S.C.A. $\S 17102$ (West 2015). Defined in the anti-trafficking statute as "any sex act on account of which anything of value is given to or received by any person." The phrase "anything of value" could translate to the cult context if that phrase is read as encompassing a broad range of benefits brought to a cult through sexual exploitation of its adherents to recruit new members.
}

34918 U.S.C.A. § 1591(2) (West 2015). 
enticing, or harboring a minor. ${ }^{350}$ This language is also broad enough that it could be used to prosecute cults. Specifically, it could be used to prosecute a leader that receives "benefits" (which includes not just money but "anything of value") from the transport of minors.

Anti-trafficking laws can also be used to prosecute cults in situations where cult leaders inflict "threats of serious harm to or physical restraint against" any person ${ }^{351}$ or threaten to engage the "legal process." 352 The statutory definition of "abuse or threatened abuse of law or legal process" is very broad and encompasses both the "use" or "threatened use" of "law or legal process"-in any conceivable category - administrative, civil, or criminal. ${ }^{353}$ It is meant to protect victims when traffickers are abusing the legal process "for any purpose of which the law was not designed" or to "exert pressure." 354

The statutory definition of "serious harm" is broad and encompasses "any harm," including physical, psychological, and other nonphysical harms. ${ }^{355}$ Alternatively, if the victim is a minor and was "caused to engage in a commercial sex act," the cult leader can also be punished. ${ }^{356}$

In passing the anti-trafficking laws, Congress recognized that "[t]raffickers often make representations to other victims that physical harm may occur to them or others should the victim escape or attempt to escape" and that "such representations can have the same coercive effects on victims." 357 Using that sentiment and the statute (in particular, the "psychological harm" language), cult prosecutors could encourage courts to expand the restrictive common law regarding mind control that is currently available.

Finally, prosecutors could utilize the portions of the anti-trafficking laws related to prohibiting certain businesses to prosecute cults. As noted, cults, like trafficking rings, are businesses. ${ }^{358}$ Whether cult leaders run a commercial enterprise in which followers directly sell to the public, or they coerce their followers into donating their labor and money to the organization, the group runs as a business. Given the

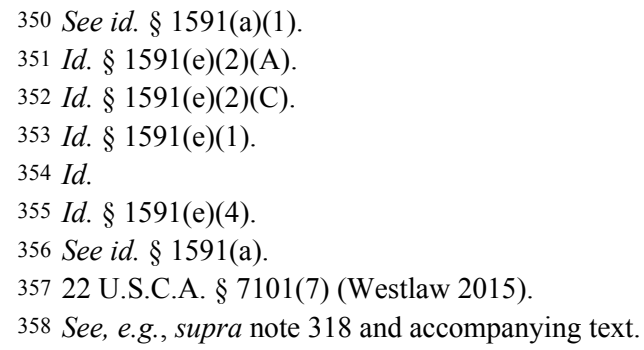


expansive language in the trafficking statutes, a creative prosecutor would not have trouble explaining how a cult functioned as a business, how the adherents were an integral part of that business, and how the leader exploited the adherents for labor, sex, or both through that business.

\section{B. Suggestions for Expanding Resources to Identify and Support Cult Victims}

\section{Violence Against Women}

Under international law, states are obligated to investigate and prosecute violence against women. ${ }^{359}$ Victims of any international crime, including human trafficking, have the right to seek and obtain reparations. ${ }^{360}$ Given the different treatment that women receive in cults (often harsher than what their fellow male members receive), these services should be provided to women who leave cults.

These services could be modeled after those already being provided to women who have overcome other forms of trauma, such as domestic abuse. For example, in U.S. states such as New York, programs are developing to provide counseling and other assistance to trafficked women. ${ }^{361}$ Those who have been in prostitution rings have protections, under state law, from being prosecuted for crimes they were forced to commit. ${ }^{362}$ In 2007, the New York legislature passed a statute that establishes an interagency task force, including the Division of Criminal Justice Service and the Office for Temporary and Disability Assistance. ${ }^{363}$ Currently, eight other state agencies participate in the task force ${ }^{364}$ Charges of the unified taskforce include the collection of data on the nature of human trafficking, and the identification of programs for victims. ${ }^{365}$ The resources being spent developing these

\footnotetext{
359 See U.N. Facts Sheet No. 36, supra note 249, at 28.

360 REDRESS, What is Reparation?, www.redress.org/what-is-reparation/what-is -reparation (last visited May 10, 2016) (citing Basic Principles and Guidelines on the Right to a Remedy and Reparation for Victims of Violations of International Human Rights and Humanitarian Law, 2005 UN General Assembly).

361 New York Social Services Law § 483-ee (West 2016) (effective October 2015, this statute established an interagency task force to assist trafficked persons).

362 See id.

363 Id.

364 N.Y. St. OfF. OF THE ATT’y GeN., Fighting Human Trafficking in New York State, http://www.ag.ny.gov/ht/fighting-human-trafficking-new-york-state (last visited Apr. 24, 2016).

365 See id.
} 
programs could be shared with programs supporting former cult members if cults are held accountable under the justice system.

\section{Training Programs}

Training programs educating attendees about trafficking prevention are now being offered abroad and in the United States, and they should continue to be developed. They should also be expanded to include information about destructive cults. Educators, hospital administrators, and others who are in frequent contact with immigrants and other populations vulnerable to trafficking should be trained to recognize the signs of trafficking. ${ }^{366}$ Specifically, training in the professional fields of "health, education, immigration, labor and employment, social service, and corporate sectors" ${ }^{\prime 367}$ is needed. In the United States, the Department of Justice provides funding for human trafficking task forces, which pool together resources from law enforcement, prosecutorial offices, women services, housing shelters, public health agencies, and other agencies. ${ }^{368}$

The trafficking task forces should become familiar with International Cultic Studies Association's ("ICSA") work with cultic groups. Formed in 1979, ICSA provides extensive counseling services and public education about cults. ${ }^{369}$ Although based in the United States, it has been holding conferences internationally. ICSA is "a global network of people concerned about psychological manipulation and abuse in cultic or high-demand groups, alternative movements, and other environments." ${ }^{370}$ ICSA offers help to former members of cultic groups and their families. Through international and domestic conferences, as well as small group workshops, ICSA provides education about cultic groups. ${ }^{371}$ It also fosters research and publications through its academic journals. ${ }^{372}$ ICSA's website includes an extensive library of articles and books. ${ }^{373}$

\footnotetext{
366 See HYLAND \& SREEHARSHA, supra note 240, at 4.

367 Id.

368 Id. at 39.

369 INT'L CUlTIC STUD. ASS'N, supra note 6.

370 Id.

371 See generally id.

372 Id.

373 Id.
} 
Another resource for cultic members and their families is Info Secte Cult in Montreal, Canada. ${ }^{374}$ "Info Secte Cult is a non-profit charitable organization founded in 1980 based in Montreal (Quebec, Canada) that offers help and information about cults, new religious movements and related groups and subjects. ${ }^{375}$ Info Secte Cult, like ICSA, provides an online library. ${ }^{376}$

\section{Providing Victims' Rights to Former Cult Members}

As victims' rights continue to develop abroad and in the United States, they should be considered in the cult context as well. Under both international and U.S. law, trafficked victims are protected from being prosecuted for crimes they were forced to commit. ${ }^{377}$ In the international arena, the Recommended Principles and Guidelines advises that "trafficked persons [should not be] prosecuted for violations of immigration laws or for the activities they are involved in as a direct consequence of their situation as trafficked persons." ${ }^{378}$ It is time that the same be recommended for victims of cults in recognition of the power of undue influence.

Victims of cults should have other legal protections already afforded to trafficked persons as well. For instance, international law provides that trafficked victims are entitled to participate in legal proceedings safely and being fully informed about the legal process. ${ }^{379}$ In the United States, some states have enacted trafficking statutes to protect victims in similar ways, ${ }^{380}$ and protecting the rights of trafficked victims is a developing legislative concern. ${ }^{381}$ For example, in New York, if a person is convicted of prostitution but has been coerced into the commercial act as a result of being trafficked, then he or she may file a post-judgment motion in state court to vacate the conviction ${ }^{382}$ where the charge was for "loitering for the purpose of engaging in a

374 INFO SECTE CULT, www.infocult.org (last visited May 10, 2016).

375 Id.

376 Id.

377 See U.N. Fact Sheet 36, supra note 249, at 17.

378 Id. at 18 . The Trafficking Protocol does not specifically address prosecution but makes a similar recommendation for countries to implement domestic legislation.

379 See id. at 15.

380 See supra text and accompanying notes 368-70; HYLAND \& SREEHARSHA, supra note 240 , at 5 .

381 See, e.g., Runaway and Homeless Youth and Trafficking Prevention Act; 42 U.S.C.A. $\S 5701$ (2016).

382 N.Y. Crim. Proc. L. $\S 440.10(1)(\mathrm{i})$ (West 2015). These motions are otherwise known as "440 motions." 
prostitution offense"383 or "prostitution."384 Similarly, when cult adherents are charged with crimes that they were duped into committing because of the power of undue influence, they too should be immune from punishment.

\section{Sharing Resources with Programs that Help Identify Child Victims}

International law provides special measures for trafficked children to be afforded their true identity and efforts are made to obtain correct information so that these children are correctly identified. ${ }^{385}$ Some cults also strip their followers of their names and identities. Often they are given new names. ${ }^{386}$ They are groomed differently and given different clothing than they wore when they were their former selves. ${ }^{387}$ When appropriate, children defecting from cults, or those gaining emancipation status, should be provided similar assistance.

\section{A Case in Point}

A case from Atlanta, Georgia, is one example of how trafficking laws were used to prosecute a leader who ran a commercial enterprise that could also be characterized as a "commercial cult." 388 This ringleader, Jimme Lee Jones, often referred to religious scripture knowing that certain recruits would identify with religion. ${ }^{389}$ Jones also rigidly controlled the recruitment and operations of a modeling agency, exploiting the models and subjecting them to physical and sexual abuse and forced prostitution. ${ }^{390}$ It could be categorized as a "commercial cult." 391

\footnotetext{
383 N.Y. Penal L. $\$ 240.37$ (West 2015).

384 Id. $\S 230.00$. Note- "loitering" for purpose of prostitution is a separate crime from that of prostitution.

385 See U.N. Fact Sheet No. 36, supra note 249, at 20 (citing UNICEF Guidelines). Often times, trafficked persons are given false names and documentation.

386 See Arnold, supra note 320 (presenting on her experience in Children of God, and that she was given a few names).

387 Id.

388 DeP'T OF Justice, Georgia Man Sentenced to 15 Years on Sex Trafficking and Mann Act Charges (Jan. 24, 2008), http://www.justice.gov/archive/opa/pr/2008/January/08_crt _058.html; Rachel Thomas, Human Trafficking as a Commercial Cult Mind-Control Phenomenon, VIMEO (July 5, 2014), vimeo.com/102628104.

389 See Thomas, supra note 388.

390 See id.

391 See id.
} 
Rachel Thomas was a college student in Atlanta who was approached by Jones on campus claiming to be a modeling agent. ${ }^{392}$ Two young women also approached Thomas, and they vouched for the man. ${ }^{393}$ They convinced Thomas to sign a modeling agency contract and fill out a W-4 tax form, which required that she reveal her permanent address where her parents lived; her current address, which she shared with roommates; and her social security number. ${ }^{394}$ Jones did obtain modeling jobs for Thomas, but she quickly saw him physically abusing another model, and Thomas tried to back out. ${ }^{395}$ At that point, Jones threatened her and her family, saying, "I own you; you do what I tell you; I know where your parents live." ${ }^{396}$ Thomas felt trapped and scared for herself, her family, and her roommates. Thereafter, he verbally and physically coerced her to perform sex for money with "buyers" and physically abused her. ${ }^{397}$

Thomas was under this man's control for at least a year. ${ }^{398} \mathrm{He}$ coerced her to perform sex acts for clients and to continue modeling, with him serving as her agent and getting paid. ${ }^{399}$ Knowing that she was raised in a Christian home, he quoted scripture to manipulate her into doing what he wanted, and he claimed to hear God's word. ${ }^{400} \mathrm{He}$ also used her to recruit other women in similar ways that she was recruited. ${ }^{401}$

Eventually, law enforcement was tipped off about this man, and Thomas was brought to a station house to discuss the business. ${ }^{402}$ Thomas began reading literature about other cults and realized that this pimp was similar to cult leaders. ${ }^{403}$ The FBI arrested Jones and posted his capture on the evening news. ${ }^{404}$ In response to a telephone hotline, over seventy-five viewers provided information to the authorities within an hour. ${ }^{405}$ Authorities learned that Jones had visited all six

\footnotetext{
392 See id.

393 See id.

394 See id.

395 See id.

396 See id.

397 See id.

398 See id.

399 See id.

400 See id.

401 See id.

402 See id.

403 See id.

404 See id.

405 See id.
} 
colleges in the Atlanta area and had recruited women from each into this prostitution ring. ${ }^{406}$

Jones was sentenced to 15 years on charges of sex trafficking and violations of the federal Mann Act. ${ }^{407}$ The Department of Justice issued a press release acknowledging that the case proved that "human trafficking can occur anytime, anywhere, and against any vulnerable victim, including U.S. citizens and college students." 408

Thomas surmises that traffickers and cult leaders have similar traits. ${ }^{409}$ In her case, the "agent" manipulated her into ${ }^{410}$ believing that God would be vengeful should she not comply with his demands. ${ }^{411} \mathrm{He}$ used other tactics with other women; for example, he acted as a father figure to women with no fathers. With over 75 victims, this modeling ring could be categorized as a "commercial cult."

What would be the result of a trafficking prosecution of Alan Steed of FLDS in the coerced marriage of fourteen-year-old Ellisa Wall to her older first-cousin $?^{412}$ Arguably, a court could use broad definitions of sex trafficking to find that Jeffs profited from forced marriages of his followers ("anything" of value). ${ }^{413}$ Would a court view membership and procreation as a form of forced servitude for the greater Church?

Whether it is a doomsday cult on our soil, or abroad, the human trafficking laws provide a framework, resources, and an international community to prevent and combat future tragedies. Recent court cases in the United States have shown courts' expanding views of the rights of trafficked victims to see restitution and freedom from their constricted employ. ${ }^{414}$ These more recent cases, and the human

\footnotetext{
406 See id.

407 DEP'T OF JUSTICE, supra note 388; see 18 U.S.C. § 2421 (West 2016) (formerly § 398) makes it an offense to transport in interstate comer females for purposes of prostitution or for other immoral purposes.

408 Id.

409 Thomas, supra note 388 .

410 Id.

411 Id.

412 See supra text accompanying notes $20-52$.

413 As discussed supra, the anti-trafficking statute prohibits "any sex act on account of which anything of value is given to or received by any person." See 22 U.S.C.A. § 17102 (West 2015). The phrase "anything of value" could be interpreted as encompassing a broad range of benefits brought to a cult through sexual exploitation of its adherents to recruit new members. Arguably, Jeffs' church benefited with increasing membership, thus procreation among its members brought the church "value."

414 See generally State v. Jeffs, 243 P.3d 1250 (Utah 2010); Menocal v. GEO Group, Inc., 113 F. Suppl. 3d 1125 (D. Colo. 2015).
} 
trafficking statutes, can be the basis for future causes of action on behalf of cult victims and in the criminal prosecution of cult leaders. 


\section{APPENDIX}

\section{Characteristics Associated with Cultic Groups}

Characteristics Associated with Cultic Groups-Revised

Michael D. Langone, Ph.D.

Concerted efforts at influence and control lie at the core of cultic groups, programs, and relationships. Many members, former members, and supporters of cults are not fully aware of the extent to which members may have been manipulated, exploited, even abused. The following list of social-structural, social-psychological, and interpersonal behavioral patterns commonly found in cultic environments may be helpful in assessing a particular group or relationship.

Compare these patterns to the situation you were in (or in which you, a family member, or friend is currently involved). This list may help you determine if there is cause for concern. Bear in mind that this list is not meant to be a "cult scale" or a definitive checklist to determine if a specific group is a cult. This is not so much a diagnostic instrument as it is an analytical tool.

The group displays excessively zealous and unquestioning commitment to its leader and (whether he is alive or dead) regards his belief system, ideology, and practices as the Truth, as law.

Questioning, doubt, and dissent are discouraged or even punished.

Mind-altering practices (such as meditation, chanting, speaking in tongues, denunciation sessions, and debilitating work routines) are used in excess and serve to suppress doubts about the group and its leader(s).

The leadership dictates, sometimes in great detail, how members should think, act, and feel (for example, members must get permission to date, change jobs, marry - or leaders prescribe what types of clothes to wear, where to live, whether or not to have children, how to discipline children, and so forth).

The group is elitist, claiming a special, exalted status for itself, its leader(s) and members (for example, the leader is considered the Messiah, a special being, an avatar-or the group and/or the leader is on a special mission to save humanity). 
The group has a polarized us-versus-them mentality, which may cause conflict with the wider society.

The leader is not accountable to any authorities (unlike, for example, teachers, military commanders or ministers, priests, monks, and rabbis of mainstream religious denominations).

The group teaches or implies that its supposedly exalted ends justify whatever means it deems necessary. This may result in members' participating in behaviors or activities they would have considered reprehensible or unethical before joining the group (for example, lying to family or friends, or collecting money for bogus charities).

The leadership induces feelings of shame and/or guilt iin order to influence and/or control members. Often, this is done through peer pressure and subtle forms of persuasion.

Subservience to the leader or group requires members to cut ties with family and friends, and radically alter the personal goals and activities they had before joining the group.

The group is preoccupied with bringing in new members.

The group is preoccupied with making money.

Members are expected to devote inordinate amounts of time to the group and group-related activities.

Members are encouraged or required to live and/or socialize only with other group members.

The most loyal members (the "true believers") feel there can be no life outside the context of the group. They believe there is no other way to be, and often fear reprisals to themselves or others if they leave (or even consider leaving) the group.

Note: This checklist has gone through many revisions since the author first presented it in the 1990s. Many people have contributed suggestions and feedback to the various revisions, in particular Carol Giambalvo, Janja Lalich, Herb Rosedale, and Patrick Ryan. 


\section{Treaties and Other Instruments Particularly Relevant to Trafficking ${ }^{415}$}

Protocol to Prevent, Suppress and Punish Trafficking in Persons, Especially Women and Children, supplementing the United Nations Convention against Transnational Organized Crime, 2000 [Trafficking Protocol]

Convention on the Elimination of All Forms of Discrimination against Women, 1979

Convention on the Rights of the Child, $1989^{416}$

Optional Protocol to the Convention on the Rights of the Child on the sale of children, child prostitution and child pornography, 2000

United Nations convention against Transnational Organized Crime, 2000

International Convention on the Protection of the Rights of All Migrant Workers and Members of Their Families, 1990

International Covenant on Civil and Political Rights, 1966

International Covenant on Economic, Social and Cultural Rights, 1966

Council of Europe, Convention on Action against Trafficking in Human Beings, 2005 [European Trafficking Convention]

Charter of Fundamental Rights in the European Union, 2000, article 5, and Directive 2011/36/EU of the European Parliament and Council on preventing and combating trafficking in human beings and protecting its victims, 2011

South Asian Association for Regional Cooperation, Convention on Preventing and Combating Trafficking in Women and Children for Prostitution, 2002

415 See U.N. Fact Sheet No. 36, supra note 249, at 10.

416 The Convention on the Rights of the Child has not been adopted by the United States. This document along with the Convention on the Elimination of All Forms of Discrimination Against Women (CEDAW) was adopted by the U.N. General Assembly in December 1979. They require that women have equal rights to work, to receive pay, to receive benefits, and to have safe working conditions. These conventions also prohibit the sexual exploitation of children and the discrimination against women in political activities. Tiefenbrun, supra note 323, at 148. 
The Following Are Influential, But Do Not Impose Obligations on Countries or Confer Rights on Trafficked Persons ("Soft law")

Recommended Principles and Guidelines on Human Rights and Human Trafficking

Basic Principles and Guidelines on the Right to a Remedy and Reparation for Victims of Gross Violations of International Human Rights Law and Serious Violations of International Humanitarian Law

UNICEF Guidelines on the Protection of Child Victims of Trafficking

Criminal Justice Responses to Trafficking in Persons: ASEAN Practitioner Guidelines

UNHCR Guidelines on international protection: The application of article 1A(2) of the 1951 Convention and/or 1967 Protocol relating to the Status of Refugees to victims of trafficking and persons at risk of being trafficked.

UN General Assembly and the Human Rights Council - UN resolutions

\section{Violence Against Women-Related Legal and Policy Documents}

Inter-American Convention on the Prevention, Punishment and Eradication of Violence against Women of the Organization of American States (1994)

Declaration on the Elimination of Violence against Women adopted by the General Assembly (1993)

General recommendation No. 19 (1992) on violence against women of the Committee on the Elimination of Discrimination against Women

Beijing Platform for Action (1995)

Nairobi Declaration on Women's and Girls' Right to a Remedy and Reparation (2007) 